\title{
1 The permeability of stylolite-bearing limestone
}

2

\section{Michael Heap', Thierry Reuschlé1, Patrick Baud1, François Renard2,3, and Gianluca Iezzi4}

${ }^{1}$ Géophysique Expérimentale, Institut de Physique de Globe de Strasbourg (UMR 7516 CNRS, Université de Strasbourg/EOST), 5 rue René Descartes, 67084 Strasbourg cedex, France. 2PGP, The Njord Centre, Departments of Geosciences \& Physics, University of Oslo, Norway ${ }^{3}$ Université Grenoble Alpes, Université Savoie Mont Blanc, CNRS, IRD, IFSTTAR, ISTerre, 38000 Grenoble, France

${ }^{4}$ Dipartimento di Ingegneria Geologia, IV Piano del Plz. Ex-Rettorato, Università degli Studi “G. d'Annunzio", Via Dei Vestini 30, 66100 Chieti, Italy.

\section{Corresponding author: M. Heap (heap@unistra.fr)}

\section{Abstract}

Stylolites are planar features that form due to intergranular pressure solution. Due to their planar geometry and relative abundance in limestone reservoirs, their impact on regional fluid flow has attracted considerable interest. We present laboratory permeability data that show that stylolites can be considered as conduits for flow in the stylolite-bearing limestones measured. A combination of analysis techniques shows that this is due to a zone that surrounds these stylolites that is more porous and contains larger pores than the host rock. Our data also show that the water permeability of a sample containing a stylolite parallel to fluid flow is typically lower than its permeability to gas, explained here as a result of the expansion of minor amounts of clay found in the stylolite, and that, due to their microstructural similarities, tectonic and sedimentary stylolites affect sample permeability similarly. Finally, we show that the permeability anisotropy that 
25 develops in the rock mass due to the presence of sedimentary stylolites makes it appear as though

26 the stylolites are acting as barriers to fluid flow, and may explain the discrepancy between

27 laboratory measurements and field-scale observations. This approach can provide estimates for the

28 equivalent permeability, and permeability anisotropy, for stylolite-bearing limestone reservoirs

29 worldwide.

30

31 Keywords: Stylolite; limestone; permeability; synchrotron X-ray computed tomography; scanning

32 electron microscopy

33 


\section{Highlights}

35

36 - Stylolites in limestones are conduits for flow, not barriers to flow.

37 - Stylolites are characterised by zone of higher porosity than the host rock.

38 - The high-porosity stylolite zone contains larger pores than in the host rock.

39

- Pores within stylolites are less spherical: stylolites create the high-porosity zone during

40 their formation.

41

- Stylolites create a permeability anisotropy that may make them falsely appear as barriers to

42 flow. 


\section{Introduction}

Stylolites are planes of insoluble minerals that form in rocks as soluble minerals are removed by pressure solution (e.g., Park and Schot, 1968; Wanless, 1979; Nenna and Aydin, 2011; Croizé et al., 2013; Toussaint et al., 2018). They are common in limestones due to the relatively high solubility of calcite (e.g., Tondi et al., 2006; Fabricius and Borre, 2007; Benedicto and Schultz, 2010; Smith et al., 2011; Rustichelli et al., 2012; Agosta et al., 2012; Laronne Ben-Itzhak et al., 2014; Rustichelli et al., 2015; Martín-Martín et al., 2018), but are also found in sandstones (Heald, 1955; Walderhaug, 1996; Bjørkum et al., 1998; Walderhaug and Bjørkum, 2003; Emmanuel et al., 2010). Stylolites form perpendicular to the major compressive stress and are commonly found sub-parallel to bedding (formed by overburden stresses; "sedimentary stylolites"), but can form subperpendicular to bedding due to tectonic stresses ("tectonic stylolites"; e.g., Railsback and Andrews, 1995; Ebner et al., 2010a). Although macroscopically planar, stylolites are morphologically variable on the meso- and microscale (e.g., Karcz and Scholz, 2003; Renard et al., 2004; Schmittbuhl et al., 2004; Rolland et al., 2012; Laronne Ben-Itzhak et al., 2012; Rolland et al., 2014; Koehn et al., 2016). Their roughness is thought to be a function of the magnitude of the stress under which they formed (e.g., Koehn et al., 2007; Ebner et al., 2009a; Koehn et al., 2012), the heterogeneity of the host material (e.g., Andrews and Railsback, 1997; Brouste et al., 2007; Ebner et al., 2009b, 2010b; Koehn et al., 2012), and/or the competition between long-range elastic redistribution and surface tension forces along the interface (e.g., Schmittbuhl et al., 2004; Renard et al., 2004).

Due to their macroscopically planar form, the influence of stylolites on fluid flow and reservoir compartmentalisation has drawn considerable interest. A handful of experimental studies have shown that stylolites can provide conduits for flow (Lind et al., 1994; Mallon and Swarbrick, 1998; Heap et al., 2014; Rustichelli et al., 2015), challenging paradigms that stylolites present barriers to fluid flow (Dunnington, 1967; Nelson, 1981; Burgess and Peter, 1985; Koepnick, 1987; Finkel and Wilkinson, 1990; Dutton and Willis, 1998; Alsharhan and Sadd, 2000). Heap et al. 
(2014), for example, measured the permeability of limestone samples that contained no stylolites, one stylolite perpendicular to the imposed fluid flow, or one stylolite parallel to flow. They found that samples containing stylolites parallel to flow were about an order of magnitude more permeable than the stylolite-free material. They concluded that this was likely due to a zone of enhanced porosity surrounding the stylolite, a conclusion supported by microstructural observations (Carozzi and von Bergen, 1987; Raynaud and Carrio-Schaffhauser, 1992; van Geet et al., 2000; Gringas et al., 2002; Padmanabhan et al., 2015). The higher porosity zone surrounding a stylolite has also been shown to reduce the uniaxial compressive strength of a stylolite-bearing sample (Baud et al., 2016). However, although stylolites themselves may act as conduits for fluid flow (e.g., Heap et al., 2014; Rustichelli et al., 2015), we highlight that they are the by-product of a process whereby dissolved materials are often precipitated into the pore space of the adjacent rock, thereby lowering the porosity, and presumably permeability, relative to the original host rock (see Toussaint et al. (2018) for a review). Therefore, formations containing abundant stylolites will likely be characterised by lower porosities and permeabilities than neighbouring stylolite-free formations. Indeed, stylolite density has been measured to be inversely proportional to porosity in some limestone formations (e.g., Alsharhan and Sadd, 2000).

We extend the study of Heap et al. (2014) by providing new porosity-permeability data for stylolite-bearing limestones. We also (1) compare the gas and water permeability of stylolitebearing limestones and (2) compare the permeabilities of limestone samples containing sedimentary and tectonic stylolites. Our experimental data are supported by microstructural observations (scanning electron microscope, SEM), multi-resolution (voxel size of 6.27 and $0.7 \mu \mathrm{m}$ ) synchrotron X-ray computed tomography (CT), and estimations of the average pore radius of the flow path used by gas particles determined using the Klinkenberg slip factor. Finally, and using our experimental data, we consider the "upscaled" permeability of a limestone rock mass containing stylolites. 


\section{Experimental materials and methods}

95

96

97

98

99

100

101

102

103

104

105

106

107

We selected six stylolite-bearing limestones for this study: two from open quarries in Burgundy (France) (Corton limestone and Comblanchien limestone, both Jurassic) and four from cores drilled around the ANDRA Underground Research Laboratory near Bure (France) (one from the Middle Jurassic "Dogger" series and three from the Late Jurassic Oxfordian stage). The porosities and gas permeabilities of some of the samples from Bure were previously presented in Heap et al. (2014). We provide here new water permeability data on these samples and new porosity and permeability (gas and water) data for additional samples taken from one of the cores from Bure (from the Late Jurassic Oxfordian stage) and the samples from Burgundy.

We first quantified the mineral content of our experimental materials using X-ray powder diffraction (XRPD). Powdered samples of each of the limestones were ground for 10 minutes in alcohol using an agate pestle and mortar. The XRPD analyses were performed on powdered mounts (using nominally zero-background Si sample holders and 10-20 mg of material) using a Bruker D$5005 \theta-2 \theta$ Bragg-Brentano diffractometer equipped with Ni-filtered $\mathrm{CuK} \alpha$ radiation. The obtained XRPD patterns were first checked for their crystalline content using search-match comparisons with XRPD standards contained in the inorganic crystal structure database (ICSD). The XRPD patterns with more than one crystalline phase were then refined using the software EXPGUI-GSAS (Larson and Von Dreele 1994; Toby 2001). EXPGUI-GSAS uses the Rietveld method to derive crystallographic parameters and phase abundances (wt. \%). More detailed descriptions of the Rietveld refinement method are reported in Iezzi et al. (2004; 2010 and references therein). XRPD analysis was performed on (1) stylolite-free material and (2) on samples cut to contain a stylolite, but with as little host rock as possible (in an attempt to identify the minerals forming the stylolite). In addition, minerals within the stylolites were also identified using energy-dispersive X-ray 
spectroscopy (EDS) during our SEM analyses. The mineral content for the Bure samples was previously presented in Heap et al. (2014).

The first of the Oxfordian limestones $(01$; depth $=159 \mathrm{~m})$ is a heterogeneous allochemical limestone that contains ooids, peloids, shell fragments, and fossil foraminifera within a micrite matrix (Figure 1a). The ooids are typically 0.1-0.25 $\mathrm{mm}$ in diameter (Figure 1a). The peloids are noticeably larger than the ooids (Figure 1a); some peloids have diameters greater than $1 \mathrm{~mm}$. Shell fragments in 01 can be many millimetres in length. 01 is predominately calcite (99 wt. \%) with subordinate dolomite ( $<1$ wt. \%) (Table 1). The second Oxfordian limestone (03; depth = $174 \mathrm{~m})$ is a well-sorted allochemical limestone that contains ooids, typically $0.25-0.5 \mathrm{~mm}$ in diameter, within a micrite matrix (Figure 1b). 03 is predominately calcite (99 wt. \%) with subordinate dolomite $(<1$ wt. \%), gypsum ( $<1$ wt. \%), and pyrite ( $<<1$ wt. \%) (Table 1). The third Oxfordian limestone (06; depth $=364 \mathrm{~m}$ ) is a very heterogeneous allochemical limestone that contains peloids, shell fragments $(>1 \mathrm{~mm})$, and fossil foraminifera $(>1 \mathrm{~mm})$ within a micrite matrix (Figure 1c). 06 is predominately calcite (99 wt. \%) with subordinate dolomite $(<1 \mathrm{wt} \%$ ) and pyrite $(<<1 \mathrm{wt}$. \%) (Table 1). The "Dogger" limestone (D3; depth $747 \mathrm{~m}$ ) is an orthochemical limestone (micrite) (Figure 1d) composed of 93 wt. \% calcite, 4 wt. \% dolomite, 3 wt. \% quartz, and subordinate pyrite $(\ll<$ wt. \%) (Table 1). Corton limestone is an allochemical limestone that contains peloids (typically $0.2-1 \mathrm{~mm}$ in diameter) within a micrite matrix (Figure 1e). Corton limestone is predominately calcite (99 wt. \%) with subordinate quartz ( $<1$ wt. \%) (Table 1). Comblanchien limestone is a heterogeneous allochemical limestone that contains ooids, peloids, shell fragments, and fossil foraminifera within a micrite matrix (Figure 1f). Allochems are typically between 0.1 and $1 \mathrm{~mm}$ in diameter (Figure 1f). Comblanchien limestone is essentially entirely calcite in composition (99 wt. \%) (Table 1).

Examples of the stylolites in these materials are shown in Figures 2, 3, 4, and 5. Qualitatively, there are clear differences between the sedimentary stylolites in terms of thickness 
142 and roughness/tortuosity (Figures 2, 3, and 4). The thickest stylolites (up to 2-3 mm) are found in 143 the D3 samples (Figure 3a). The stylolites in Corton limestone are the most rough/tortuous (Figure 144 4a); the least rough/tortuous stylolites are found in samples 03 (Figure 2b) and the Comblanchien 145 limestone (Figure 4b). Stylolites found in the most heterogeneous limestone-sample 06-are 146 correspondingly anastomosing (Figure 2c). We also provide images of tectonic and sedimentary 147 stylolites found in sample 03 (Figure 5). There are no discernable differences between the thickness and roughness/tortuosity between the tectonic and sedimentary stylolites in sample 03 (Figure 5). A combination of XRPD and EDS analyses found that the stylolites typically consist of dolomite and/or quartz, with minor quantities of pyrite and organic matter/clay (Table 1). Cylindrical samples (20 $\mathrm{mm}$ in diameter and nominally $40 \mathrm{~mm}$ in length) were cored from the blocks/cores. Samples were prepared to contain (1) one stylolite perpendicular to the axis of 153 the core (i.e. perpendicular to the imposed flow direction), (2) one stylolite parallel to the axis of the core (i.e. parallel to the imposed flow direction), or (3) no stylolite (where possible, stylolitefree samples were prepared in two or three orthogonal directions). The samples containing no stylolites were typically prepared from material 5-10 $\mathrm{cm}$ from the stylolite studied. We also 157 prepared samples containing tectonic stylolites either perpendicular or parallel to the core axis 158 from one of the Oxfordian limestones (sample 03). We note that, following sample preparation, our 159 samples did not contain any obvious stylolite-associated fractures. Representative photographs of 160 the $20 \mathrm{~mm}$-diameter samples prepared for laboratory testing (stylolite-free, one stylolite 161 perpendicular to the sample axis, and one stylolite parallel to the sample axis) are provided in 162 Figures 6 and 7. Figure 8 shows photographs of samples of 03 containing tectonic and sedimentary 163 stylolites.

The connected porosity of each sample was determined using the triple weight water 165 saturation technique (Guéguen and Palciauskas, 1994). Gas (argon or nitrogen) and water (distilled water) permeabilities were then measured in a hydrostatic pressure vessel under a confining 
pressure of $2 \mathrm{MPa}$. All measurements of water permeability were performed using the steady-state

flow method. Following microstructural equilibrium, a pressure differential was imposed across the sample and the flow rate was measured using an electronic balance (with a precision $\pm 0.0005 \mathrm{~g}$ ). Once steady-state flow had been established, the water permeability $k_{\text {water }}$ was determined using Darcy's relation:

172

$$
\frac{Q}{A}=\frac{k_{w a t e r}}{\eta L}\left(P_{u p}-P_{\text {down }}\right)
$$

where $Q$ is the volumetric flow rate, $A$ is the cross-sectional area of the sample, $P_{u p}$ and $P_{\text {down }}$ represent the upstream and downstream pressure, respectively (where $P_{\text {down }}$ is the atmospheric pressure), $L$ is the length of the sample, $k_{\text {water }}$ is the permeability to water, and $\eta$ is the viscosity of

177 the pore fluid (taken here as $1.008 \times 10^{-3} \mathrm{~Pa} \mathrm{~s}$ ). A pressure differential (i.e. $P_{u p}-P_{\text {down }}$ ) of $0.5 \mathrm{MPa}$ 178 was used for all measurements reported herein. (for high-permeability samples) or the pulse-decay method (for low-permeability samples). For the steady-state method, a pressure differential was imposed across the sample (following

$$
\frac{Q}{A}=\frac{k_{\text {gas_raw }}}{\eta L} \frac{\left(P_{\text {up }}\right)^{2}-\left(P_{\text {down }}\right)^{2}}{2 P_{\text {down }}}
$$

where $\eta$, the viscosity of the pore fluid, was taken as $2.21 \times 10^{-5}$ and $1.78 \times 10^{-5} \mathrm{~Pa}$ s for argon and nitrogen, respectively. Steady-state volumetric flow rate $Q$ measurements were taken under several 
pore pressure differentials (i.e. $P_{u p}-P_{\text {down }}$, where $P_{\text {down }}$ is the atmospheric pressure) to check whether any auxiliary corrections were required. We first plot $1 / k_{\text {gas_raw }}$ as a function of $Q$ to check whether the Forchheimer correction is required (Forchheimer, 1901). The correction is necessary if these data can be well described by a linear fit with a positive slope. The Forchheimercorrected permeability is taken as the inverse of the $y$-intercept of the best-fit linear regression in the plot of $1 / k_{\text {gas_raw }}$ as a function of $Q$. If the Forchheimer correction is not required, we then check whether the Klinkenberg correction is required (Klinkenberg, 1941). To do so, we plot $k_{\text {gas_raw }}$ as a function of the reciprocal mean pressure $1 / P_{m}$, where $P_{m}$ is the mean pore fluid pressure (i.e. $\left(P_{u p}+P_{\text {down }}\right) / 2$ ). The Klinkenberg correction is required if these data can be well described by a linear fit with a positive slope and, if true, the Klinkenberg-corrected permeability can be taken as the $y$-intercept of the best-fit linear regression in the plot of $k_{\text {gas_raw }}$ as a function of $1 / P_{m}$. The Klinkenberg correction was required for all samples measured using the steady-state method; the Forchheimer correction was not required.

We used the pulse-decay method (Brace et al., 1968) to measure the gas permeability of the low-permeability samples. Following microstructural equilibrium at the target confining pressure, the decay of an initial pore pressure differential $\left(P_{u p}-P_{\text {down }}=0.5 \mathrm{MPa}\right.$, where $P_{\text {down }}$ is the atmospheric pressure) was monitored using a pressure transducer following the closure of the upstream pressure inlet. The gas permeability $k_{\text {gas_raw }}$ was then determined using the following relation:

$$
k_{\text {gas_raw }}=2 \frac{\eta L}{A} \frac{V_{u p}}{P_{u p}^{2}-P_{\text {down }}^{2}} \frac{d P_{u p}}{d t}
$$

where $V_{u p}$ is the volume of the upstream pore pressure circuit $\left(7.8 \times 10^{-6} \mathrm{~m}^{3}\right)$ and $t$ is time. As before, we checked whether these data required any auxiliary corrections (the Forchheimer or 
212 Klinkenberg correction). The Klinkenberg correction was required for all samples measured using 213 the pulse-decay method; the Forchheimer correction was not required. A detailed description of 214 these permeability methods is available in Heap et al. (2017).

3 Results

The gas permeability data for the stylolite-free limestones as a function of connected porosity are shown in Figure 9a. The data of Lind et al. (1994), a study that also measured the permeability of stylolite-bearing carbonate rocks, are also included on Figure 9 because they preserve a higher porosity (porosity $>0.2$ ) than the samples measured herein. Our data show that gas permeability increases as connected porosity is increased, in accordance with previously 222 published studies on the permeability of limestones (e.g., Ehrenberg et al., 2006; Zinszner and 223 Pellerin, 2007), and that there is no measurable permeability anisotropy in the studied materials 224 (Figure 9a contains data on samples cored in orthogonal directions, see Table 2). The difference between permeability to gas and permeability to water in the stylolite-free samples appears to depend on the connected porosity: permeability to gas can be a factor of 4.5 higher at low porosity 227 (porosity $<0.05$ ) and the ratio between gas and water permeability is essentially unity at the 228 highest tested porosity (porosity 0.15) (Figure 10a). and parallel to flow) limestones are shown in Figure 9b, together with the high-porosity (porosity > 0.2) data of Lind et al. (1994). Our data show that (1) the permeabilities of the samples containing stylolites perpendicular to the direction of flow are similar to those of the stylolite-free samples and (2) the permeabilities of the samples containing stylolites parallel to the direction of flow are 234 characterised by permeabilities higher than those of the stylolite-free samples (Figure 9b). In detail, 235 we notice that larger differences between the permeability of the samples containing stylolites 236 parallel to the direction of flow and the stylolite-free samples are observed at lower connected 
porosities (Figure 9b). For example, the permeability of stylolite-bearing Corton limestone

238 (porosity $\sim 0.03$ ) can be two or three orders of magnitude higher than the stylolite-free material

239 (Figure 9b). The ratio of gas to water permeability for all the samples tested (including stylolite-free 240 samples and samples containing stylolites perpendicular and parallel to flow) is plotted as a 241 function of connected porosity in Figure 10b. As for the stylolite-free limestones (Figure 10a), high242 porosity (porosity $\sim 0.15$ ) samples containing stylolites show little difference between gas and 243 water permeability (Figure 10b). The gas permeabilities of the low-porosity samples containing 244 stylolites are higher than their water permeabilities; this is especially true for the low-porosity 245 samples containing stylolites parallel to flow (the difference for one sample is more than an order 246 of magnitude) (Figure 10b).

247 Our data also show that there is essentially no difference between the influence of 248 sedimentary and tectonic stylolites on the permeability of our limestone samples (Figures 9b and 249 10b; Table 2).

\section{Discussion}

\subsection{Barriers to or conduits for fluid flow?}

Our new permeability data are in agreement with the conclusion of Heap et al. (2014) and 255 Rustichelli et al. (2015): the stylolites measured are not barriers to flow, but conduits for flow 256 (Figure 9b). Heap et al. (2014) postulated that a zone of higher porosity surrounds a stylolite and 257 that it is this high-porosity zone that enhances the circulation of fluids, as suggested by Carozzi and 258 von Bergen (1987), Raynaud and Carrio-Schaffhauser (1992), and Van Geet et al. (2000). The 259 greater increase in permeability in the low-porosity samples (when comparing the permeability of 260 a stylolite-free sample to a sample containing a stylolite parallel to flow) (Figure 9b) is likely a 261 consequence of their low matrix permeabilities. Conduits for flow have a much greater impact on 
the equivalent permeability of low-porosity samples than on high-porosity samples, since the matrix permeability of a high-porosity sample is much closer to the permeability of the fracture (as 264 observed in variably porous fractured materials; e.g., Heap and Kennedy, 2016; Kushnir et al., 265 2018).

To image the hypothesised zone of higher porosity, we first provide a backscattered scanning electron microscope (BSE) image of a stylolite within sample D3, selected due to its low matrix porosity and permeability. This image shows that the matrix-stylolite interface is populated by numerous micropores, typically only a few microns in diameter (white arrows; Figure 11). To better resolve the porosity, and distribution of porosity, around a stylolite, we also provide multi271 resolution (voxel size of 6.27 (beamline MB05) and $0.7 \mu \mathrm{m}$ (beamline ID19) and energy of $35 \mathrm{keV}$ ) three-dimensional X-ray tomography imaging performed on a stylolite within sample D3 at the 273 European Synchrotron Radiation Facility (Grenoble, France). Because of the high-contrast between the porosity and the minerals that comprise the rock (primarily calcite, quartz, and dolomite; Table 275 1), it is straightforward to segment the porosity so that individual pores can be imaged (Figure 12). 276 The segmented images show that the stylolite is associated with a zone of high porosity (Figure 12), 277 as previously measured by Baud et al. (2016). In particular, we observe that (1) the pores 278 surrounding the stylolite are larger than those within the host rock (Figure 12) and (2) some of the 279 pores are aligned with the teeth of the stylolite and are characterised by a "finger-like" shape 280 (Figure 13). Indeed, analysing the X-ray tomography data (similar to X-ray tomographic analyses performed on intact porous limestones by Ji et al., 2012; 2014) show that the pores are larger inside the stylolite (Figure 14a) and that the pores within the stylolite are characterised by lower values of sphericity (where 1.0 is a perfect sphere; sphericity is defined using the Thermo Scientific 284 Avizo toolbox as $\left(\frac{1}{\text { Shape }_{V A 3 D}}\right)^{1 / 3}$ where Shape ${ }_{V A 3 D}=\operatorname{Area}_{3 D}{ }^{3} /\left(36 \times \pi \times\right.$ Volume $\left._{3 D}{ }^{2}\right)$ ) (Figure 14b). 285 The volume of an individual pore within the stylolite varies from a few $\mu \mathrm{m}^{3}$ up to $>10^{5} \mu \mathrm{m}^{3}$; the 286 volume of the pores outside the stylolite are all $<10^{4} \mu \mathrm{m}^{3}$ (Figure 14a). The average equivalent 
diameter of the pores inside and outside the stylolite is $36.5 \mu \mathrm{m}$ (standard deviation of $26.8 \mu \mathrm{m}$ ) and $11.1 \mu \mathrm{m}$ (standard deviation of $4.7 \mu \mathrm{m}$ ), respectively. Sphericity inside and outside the stylolite varies from 0.2 to 0.4 and 0.4 and 0.9 , respectively (Figure 14b). Since the shape of the pores are sometimes linked to the shape of the stylolite (Figure 13), we additionally conclude that such porosity is likely the consequence of stylolite formation (in agreement with the conclusions of Raynaud and Carrio-Schaffhauser (1992) and Carozzi and von Bergen (1987)), rather than that stylolites form preferentially in a zone of higher porosity (as hypothesised by Braithwaite, 1989). To complement these microstructural data, we use the Klinkenberg slip factor, $b$ (which has the units of pressure; Table 2) (Klinkenberg, 1941), to provide an independent assessment of the average pore radius used by the gas molecules. Since the pore radius determined using this technique uses data from permeability experiments, it will therefore yield the average pore throat radius (in contrast to the $\mathrm{CT}$ data, which provides information on the pores). Since the mean free path is inversely proportional to $P_{m}$, Poiseuille's law for gas flow in a cylindrical tube and Darcy's law for flow in porous media yields the following relation:

301

$$
k_{\text {gas }}=k_{\text {gas_raw }}\left(1+\frac{b}{P_{m}}\right)
$$

302

where $k_{g a s}$ is the true (i.e. Klinkenberg-corrected) gas permeability (Klinkenberg, 1941). The average pore throat radius of the flow path followed by the gas molecules, $r$, can be estimated using the following relation (Civan, 2010):

306

$$
r=\frac{4}{b} \eta \sqrt{\frac{\pi R_{g} T}{2 M_{w}}}
$$


where $R_{g}$ is the ideal gas constant (taken as $8.31 \mathrm{~J} \mathrm{~mol}^{-1} \mathrm{~K}^{-1}$ ), $T$ is the temperature (taken as $293 \mathrm{~K}$ ), 309 and $M_{w}$ is the molar mass of the pore fluid (taken as 0.03995 and $0.02802 \mathrm{~kg} \mathrm{~mol}^{-1}$ for argon and nitrogen, respectively). The Klinkenberg slip factor has previously been used to examine the average pore throat radius of the flow path in rocks such as shales (e.g., Heller et al., 2014; Firouzi et al., 2014; Letham and Bustin, 2016) and, more recently, volcanic rocks (Heap et al., 2018) using the same, or similar, method (i.e. Equation (5)). We find that the average pore throat radius of the flow path followed by the gas molecules in the stylolite-free samples, excluding the Corton 315 limestone samples, varies between $\sim 0.05$ and $0.15 \mu \mathrm{m}$ (Figure 15a). Excluding Corton limestone, the samples containing the highest porosities (porosity $\sim 0.15$ ) are characterised by the largest pore throat radii $(\sim 0.1$ to $\sim 0.15 \mu \mathrm{m}$; Figure $15 \mathrm{a})$. The average pore throat radius of the flow path followed by the gas molecules is much larger in Corton limestone, varying between $\sim 0.2$ and 0.35 $\mu \mathrm{m}$ (Figure 15a). Although not obvious from our microstructural observations (Figure 1e), Corton limestone must contain larger pore throats than the other limestones measured herein. The average pore throat radii of the flow paths followed by the gas molecules in the samples containing stylolites (together with the stylolite-free samples) are provided in Figure 15b. The data show that (1) the pore throat radii forming the flow path in the samples containing stylolites perpendicular to 324 flow are similar to the stylolite-free samples and (2) the pore throat radii along the flow path 325 parallel to the stylolite are systematically larger than those of the other samples (Figure 15b). These data suggest that the stylolites are associated with pore throats with larger radii than those

327 that typify the host rock. This conclusion is in agreement with our X-ray tomography analysis, 328 which shows that the pores are larger inside the stylolite than in the host rock (Figure 14a). As 329 expected, the radii predicted using Equation (5) are much smaller (typically < $1 \mu$ m; Figure 15) than 330 the range of radii predicted from the X-ray tomography analysis (up to a few tens of microns). This 331 is because the Klinkenberg analysis (Equation 5) yields the pore throat radius and the X-ray 332 tomography analysis yields the pore radius. 
We conclude here that stylolites present conduits for, rather than barriers to, flow (Figure

9b) in limestones measured herein. This can be explained by a zone of elevated porosity (Figure 12) that contains pores and pore throats with larger radii than the host rock (Figures 14a and 15a), which we conclude must develop around a stylolite during its formation. The development of stylolitic porosity is discussed in detail in Carozzi and von Bergen (1987) and is considered the result of grainscale heterogeneities in the rock during the dissolution process.

\subsection{Differences between tectonic and sedimentary stylolites}

Our permeability data suggest, for the materials studied herein, that there is essentially no difference between the influence of sedimentary and tectonic stylolites on the permeability of a stylolite-bearing sample: both sedimentary and tectonic stylolites are conduits for fluid flow (Figure 9b; Table 2). This is perhaps not surprising since they are very similar on the microscale (Figure 5) and on the sample lengthscale (Figure 8). The fact that tectonic stylolites are also conduits for flow (Table 2) further supports the hypothesis that stylolites create a zone of higher porosity during their formation (e.g., Raynaud and Carrio-Schaffhauser, 1992; Carozzi and von Bergen, 1987), rather than that they form preferentially in higher porosity layers (e.g., Braithwaite, 1989).

\subsection{Differences between gas and water permeability}

Differences between permeability to gas and water are typically observed in the presence of swelling clays (e.g., Faulkner and Rutter, 2000, 2003; Tanikawa and Shimamoto 2006; Davy et al., 2007; Tanikawa and Shimamoto 2009; Behnsen and Faulkner, 2011). Our XRPD analyses highlight that clays are below the detection limit in the stylolite-free material (Table 1). It is therefore perhaps surprising that we see about a fourfold difference between gas and water permeability in the low-porosity limestones (Figure 10a). A recent study found that the permeability to gas was 
higher than permeability to water in two volcanic rocks (basalt and andesite) by a factor of up to 359 five (Heap et al., 2018). In the absence of significant physicochemical reactions, these authors suggested that the difference in gas and water permeabilities is likely due to water adsorption on the surface of thin microstructural elements. For the stylolite-free limestones, we find that there is essentially no difference between the gas and water permeabilities for the samples characterised by the largest average pore throat radii $(\sim 0.1$ to $\sim 0.15 \mu \mathrm{m})$ (Table 2$)$, as determined using the Klinkenberg slip factor. Samples with average pore throat radii between $\sim 0.05$ and $0.1 \mu \mathrm{m}$ are more permeable to gas than to water (Table 2). Similar to the conclusions drawn by Heap et al. (2018), we conclude here that, in the absence of clay within the intact materials (Table 1), the difference in gas and water permeabilities is likely due to water adsorption on the surface of thin $(\sim 0.05$ to 0.1 $\mu \mathrm{m})$ microstructural elements.

Measurements of gas and water permeability on the samples containing stylolites show that samples containing stylolites parallel to flow are often more permeable to gas than water, by up to one order of magnitude (Figure 10b). Since average pore throat radius of the flow path followed by

372 the gas molecules is relatively high for these samples (up to $\sim 1 \mu \mathrm{m}$; Figure $15 \mathrm{~b}$ ), we conclude that 373 the difference in gas and water permeabilities in these samples are due to minor quantities of clay 374 found within the stylolite (identified by EDS during our SEM analyses; Table 1). The expansion of 375 clay minerals in contact with water constricts pore throats and thus reduces permeability (e.g., $376 \quad$ Faulkner and Rutter, 2003).

4.4 Implications for fluid flow in limestone reservoirs

Limestone forms an important component of the Earth's continental crust (Ehrenberg et al., 2006; Ford and Williams, 2013) and, as a result, the permeability of limestone reservoirs is not only 381 important for fluid flow and pore pressure distribution within the crust, but also for the 382 exploitation of hydrocarbon reserves. 
Our study shows that stylolites in limestone present conduits for flow (Figure 9b) due to a

zone of elevated porosity, containing pores with larger radii than the host rock, which develops around a stylolite during its formation (Figures 11, 12, 14, and 15). In order to consider fluid flow in stylolite-bearing limestone reservoirs, we must first upscale our laboratory measurements. One method to upscale such laboratory data is to first extract the permeability of a stylolite. The permeability of a stylolite, $k_{\text {stylo }}$, can be determined using a two-dimensional model that considers flow in parallel layers (the same model used to determine the permeability of compaction bands in Vajdova et al. (2004) and fractures in Heap and Kennedy (2016), Farquharson et al. (2016), and Kushnir et al. (2018)):

$$
k_{\text {stylo }}=\frac{\left(A \cdot k_{e}\right)-\left(A_{\text {intact }} \cdot k_{0}\right)}{A_{\text {stylo }}}
$$

where $A$ is the cross-sectional area of the sample, $k_{e}$ is the equivalent permeability (the permeability of the stylolite-bearing sample), $A_{\text {intact }}$ is the area of stylolite-free material, $k_{0}$ is the stylolite-free permeability, and $A_{\text {stylo }}$ is the area of the stylolite. For the purpose of this exercise, we will consider a core of Dogger limestone (D3) taken from the ANDRA Underground Research Laboratory at Bure (Figure 16). To calculate $k_{\text {stylo }}$ we use the permeability of the stylolite-free sample of D3 $\left(k_{0}=3.69 \times 10^{-19} \mathrm{~m}^{2}\right.$; Table 2$)$. The equivalent permeability, $k_{e}$, is permeability of the D3 sample containing a stylolite parallel to the direction of flow $\left(k_{e}=5.98 \times 10^{-18} \mathrm{~m}^{2}\right.$; Table 2$)$, and we use a stylolite thickness of $1 \mathrm{~mm}$ (a reasonable approximation of the thickness of the stylolite in this sample; Figure 6d). Using these values, Equation (6) yields a stylolite permeability, $k_{\text {stylo }}$, of $8.85 \times 10^{-17} \mathrm{~m}^{2}$. We can now model the equivalent permeability of a rock mass populated with stylolites using our value for $k_{\text {stylo }}$ and the following relation: 


$$
k_{e}=\frac{\left(w_{\text {intact }} \cdot k_{0}\right)+\left(w_{\text {stylo }} \cdot k_{\text {stylo }}\right)}{W}
$$

406

407

408

409

410

411

412

413

414

415

416

417

418

419

420

421

422

423

424

425

426

427

428

where $w_{\text {intact }}$ is the total width of the intact material, $w_{\text {stylo }}$ is the total width of the stylolites, and $W$ is the length of rock considered $\left(W=w_{\text {intact }}+w_{\text {stylo }}\right)$. The Dogger limestone core sample shows that there are five sedimentary stylolites over a length of about $25 \mathrm{~cm}$ (i.e. a stylolite density of $20 \mathrm{~m}^{-1}$ ) (Figure 16). Although stylolite thickness varies (Figure 16) we will, for simplicity, assume that the thickness of each stylolite is $1 \mathrm{~mm}$. Therefore, according to our model (Equation (7); $W=$ $\left.250 \mathrm{~mm} ; w_{\text {stylo }}=5 \mathrm{~mm} ; w_{\text {intact }}=245 \mathrm{~mm} ; k_{0}=3.69 \times 10^{-19} \mathrm{~m}^{2} ; k_{\text {stylo }}=8.85 \times 10^{-17} \mathrm{~m}^{2}\right)$, the equivalent permeability parallel and perpendicular to bedding for the limestone core shown in Figure 16 is $1.80 \times 10^{-17}$ and $3.69 \times 10^{-19} \mathrm{~m}^{2}$, respectively. In other words, the $25 \mathrm{~cm}$-long sample is 50 times more permeable parallel to bedding than perpendicular to bedding. Therefore, although stylolites are conduits for flow, they can create a permeability anisotropy in a rock unit or reservoir that may make it appear that they form barriers to fluid flow (because permeability perpendicular to bedding is lower than the permeability parallel to bedding) and may therefore explain the discrepancy between laboratory measurements (that suggest that stylolites are conduits) and fieldscale investigations (that suggest that stylolites are barriers). It is important to highlight that these equivalent permeability estimates for a stylolite-bearing rock mass are just one snapshot in the porosity-permeability evolution of this limestone formation. For example, it is likely that, prior to pressure-solution and the formation of the stylolites, the host rock was much more porous and more permeable. Although not considered in our simple model, we note that the presence of stylolites perpendicular to bedding (i.e. tectonic stylolites) will reduce such permeability anisotropy. Indeed, if the number of tectonic stylolites equals the number of sedimentary stylolites, no permeability anisotropy will be observed. Although tectonic stylolites are not uncommon in limestone reservoirs (Railsback and Andrews, 1995; Ebner et al., 2010a; Figure 8), it is difficult to 
assess their density at the ANDRA Underground Research Laboratory at Bure due to the drilling

430 direction (perpendicular to bedding). The simple method presented above can be easily adapted to

431 provide estimates for the equivalent permeability, and permeability anisotropy, for stylolite-

432 bearing (both sedimentary and tectonic) limestone reservoirs worldwide.

Although we conclude here that our stylolites form conduits for fluid flow, we cannot rule out that some stylolites, different to those measured here, may provide barriers to flow. For example, (1) stylolites may provide barriers to flow if they are characterised by thick and continuous layers of clay-rich material, (2) an abstract by Corwin et al. (1997) suggests that

437 stylolites associated with a cemented zone could be of lower permeability than the surrounding 438 host rock, and (3) the modelling of Koehn et al. (2016) suggests that stylolites with simple 439 geometries (e.g., "simple wave-like type") may be more likely to provide barriers to flow. We also highlight that, due to differences in mineral composition and microstructure, the influence of stylolites on the permeability of sandstone may differ from their influence on the permeability of carbonate rocks (e.g., Walderhaug and Bjørkum, 2003; Emmanuel et al., 2010).

445 laboratory measurements on stylolites that are characterised by thick and continuous layers of 446 clay-rich material are now required to further explore the role of stylolites on the regional-scale 447 permeability of limestone reservoirs (as concluded by Bruna et al., 2018). Laboratory measurements on stylolite-bearing sandstones also offer an interesting avenue for future research.

\section{Conclusions}

The salient conclusions of this study can be summarised thusly:

(1) The stylolites measured herein are conduits for fluid flow, not barriers to fluid flow. 
(2) The permeability of a stylolite-bearing sample is lower when measured with water than with gas. We interpret this here as the result of the expansion of minor quantities of clay found within the stylolite. The expansion of clay minerals constricts pore throats and thus reduces permeability.

(3) Sedimentary and tectonic stylolites affect sample permeability similarly. We interpret this as a result of their similar microstructures.

(4) X-ray tomography data show that the stylolites are surrounded by a zone of higher porosity that is characterised by pores larger than those found in the intact material. This explains why the stylolites measured herein are conduits for fluid flow.

(5) The presence of larger pores within the stylolite zone is supported by an analysis of the Klinkenberg slip factor, which highlights that the average pore throat radius of the flow path followed is larger when the sample contains a stylolite parallel to flow.

(6) X-ray tomography data show that the pores within the stylolite are much less spherical than those of the host rock and that they are sometimes aligned with the teeth of the stylolite. Since the shape of the pores are linked to the shape of the stylolite, we conclude that such porosity is likely the consequence of stylolite formation, rather than that stylolites form preferentially in a zone of higher porosity.

(7) Upscaling our laboratory measurements using a simple two-dimensional model that considers flow in parallel layers shows that the equivalent permeability of a stylolitebearing limestone rock mass is higher parallel to bedding than perpendicular to bedding.

(8) The permeability anisotropy that develops in the rock mass due to the presence of stylolites makes it appear as though the stylolites are acting as barriers to fluid flow (since permeability perpendicular to bedding is lower than the permeability parallel to bedding) and may explain the discrepancy between laboratory measurements and field-scale observations. 


\section{Acknowledgements}

This research was partly funded by CNRS and ANDRA (FORPRO program) and the

481 Norwegian Research Council (project ARGUS, grant 272217). We would like to thank Alexandra

482 Rolland, Silvio Mollo, Gilles Morvan, and Bertrand Renaudié. We thank Gilles Jouillerot (Rocamat

483 Pierre Naturelle) for his help selecting the materials at Comblanchien and Elodie Boller for her help

484 at the European Synchrotron Radiation Facility (beamline ID19). The comments of Einat Aharonov

485 and one anonymous reviewer helped improve this manuscript.

486

487 Data availability

488 Most of the data used in this study are available in Tables 1 and 2. The X-ray tomography 489 data may be made available on request (to François Renard). 
492 Figure 1. Optical microscope images of the stylolite-free (host rock) material for the studied

493 limestones. (a) Sample 01 - Oxfordian limestone from Bure. (b) Sample 03 - Oxfordian limestone

494 from Bure. (c) Sample 06 - Oxfordian limestone from Bure. (d) Sample D3 - "Dogger" limestone

495 from Bure. (e) Corton limestone from Burgundy. (f) Comblanchien limestone from Burgundy.
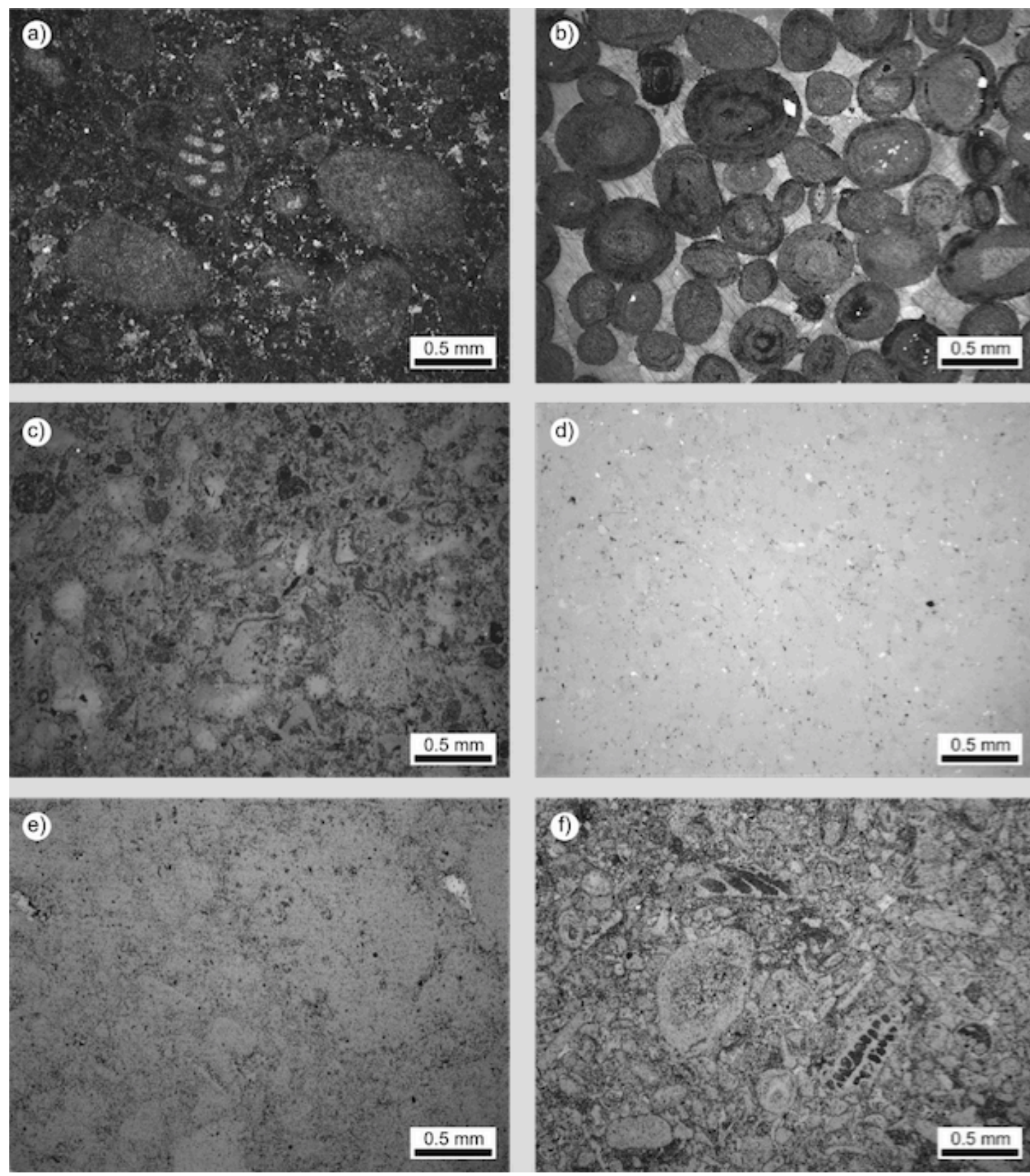
497 Figure 2. Optical microscope images of the stylolites found within studied limestones. (a) Sample 49801 - Oxfordian limestone from Bure. (b) Sample 03 - Oxfordian limestone from Bure. (c) Sample 49906 - Oxfordian limestone from Bure.

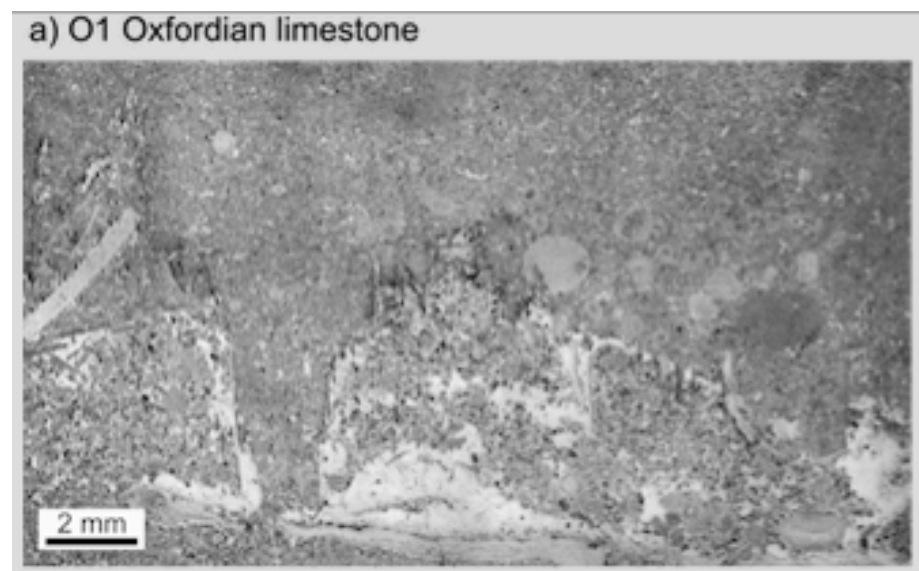

b) $\mathrm{O} 3$ Oxfordian limestone

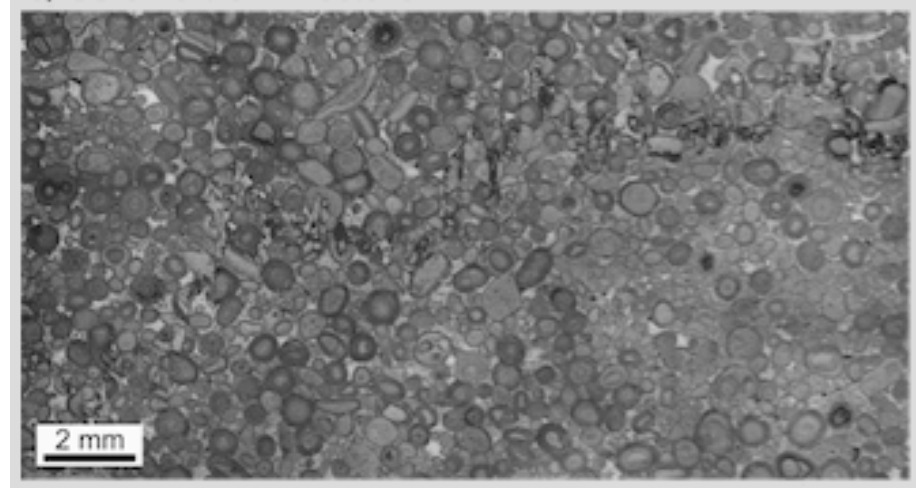

c) 06 Oxfordian limestone

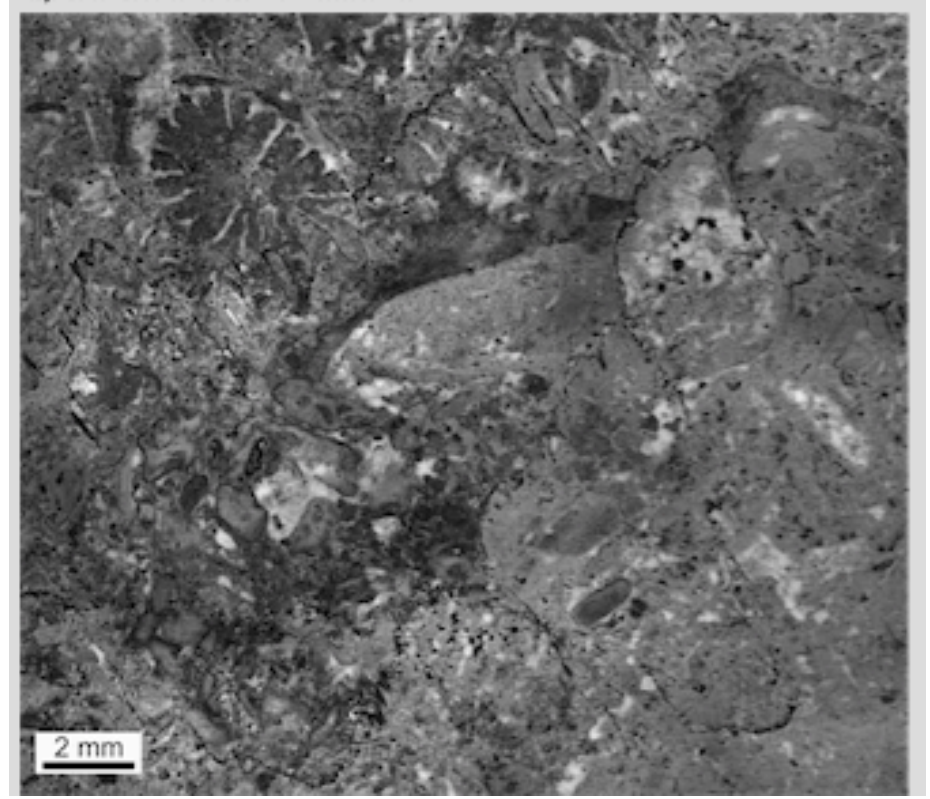


501 Figure 3. Optical microscope images of the stylolites found within studied limestones. (a) Sample 50206 - Oxfordian limestone from Bure. (b) Sample D3 - "Dogger" limestone from Bure.
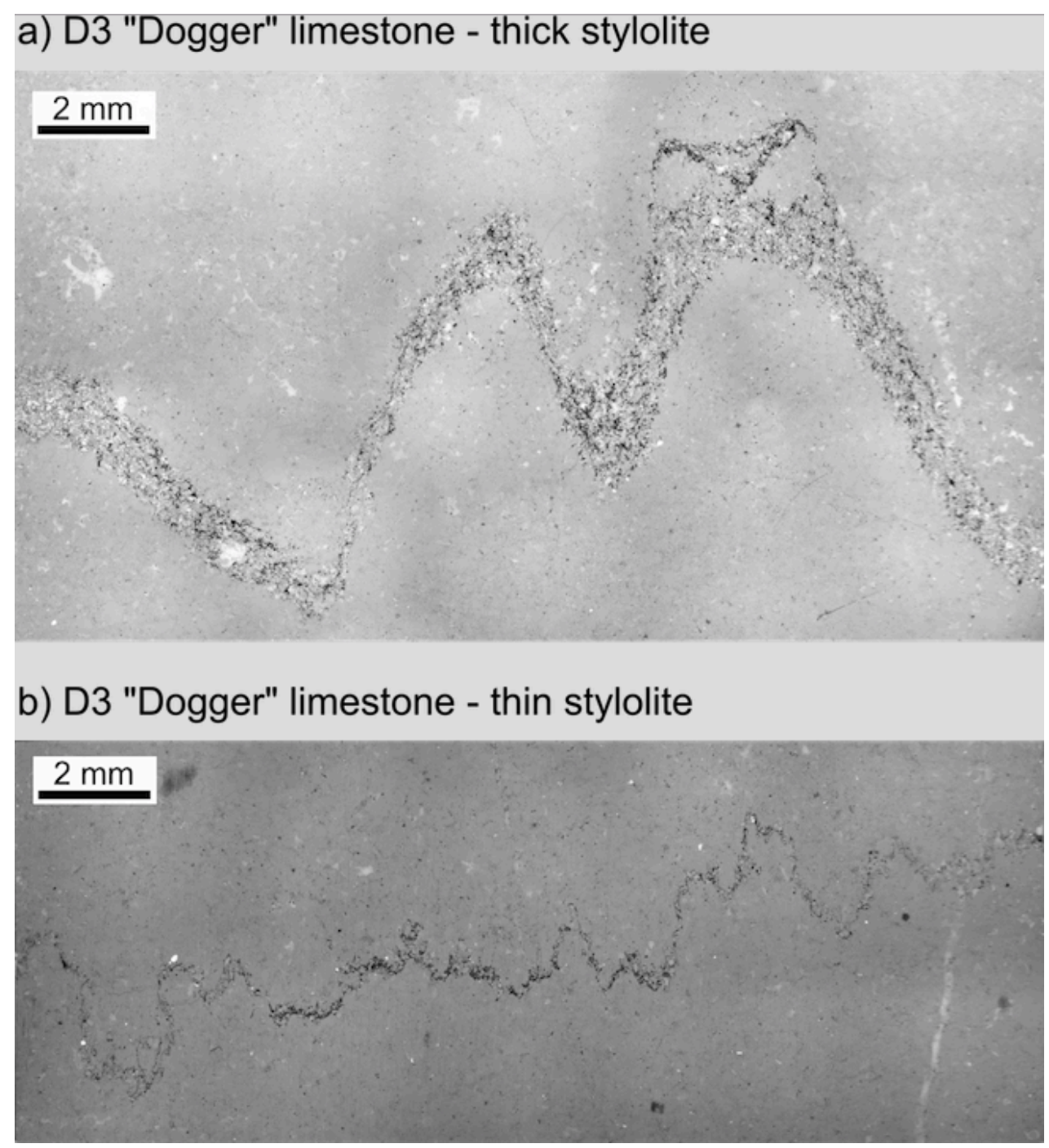
Figure 4. Optical microscope images of the stylolites found within studied limestones. (a) Corton 506 limestone from Burgundy. (b) Comblanchien limestone from Burgundy.
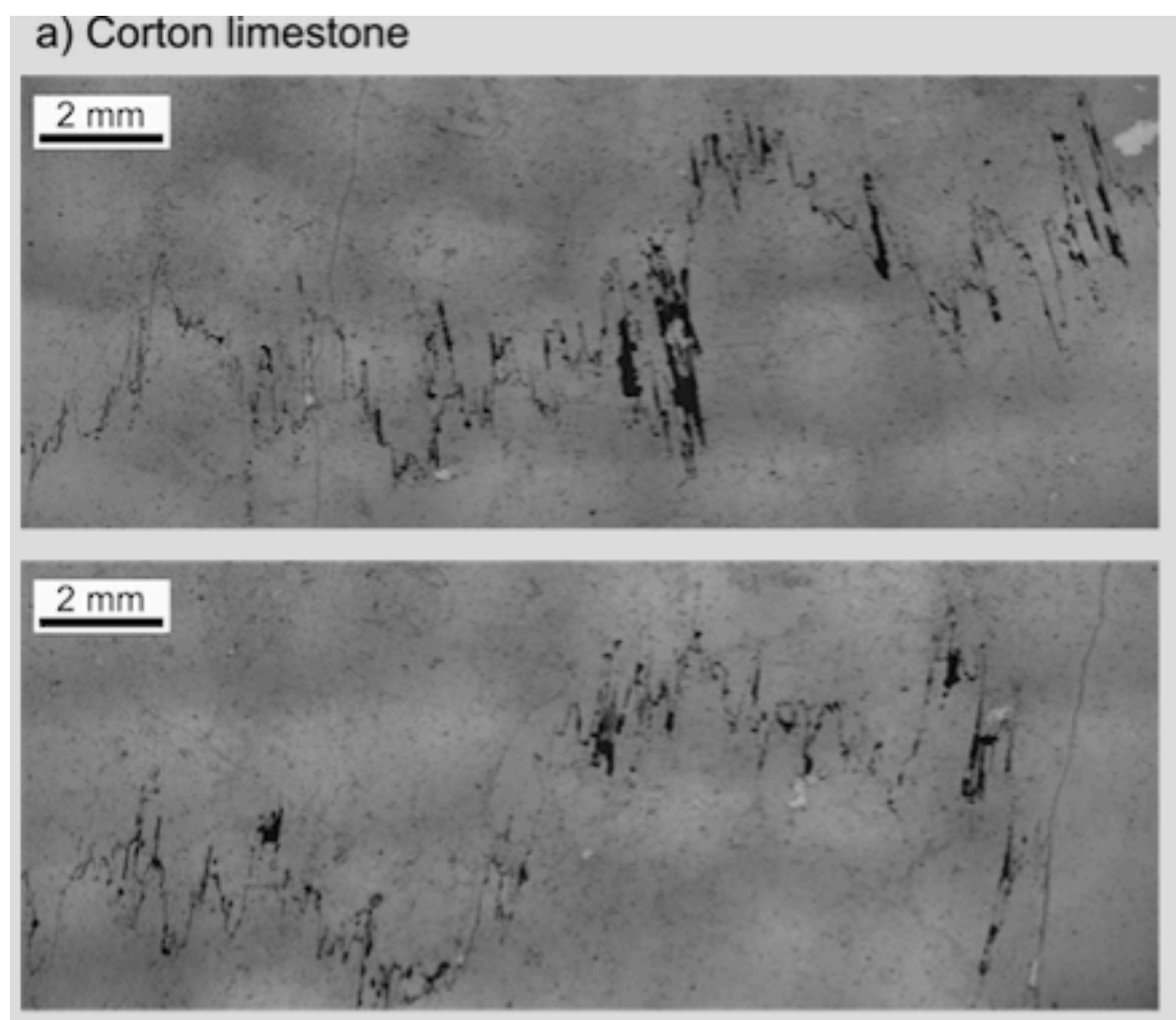

\section{b) Comblanchien limestone}
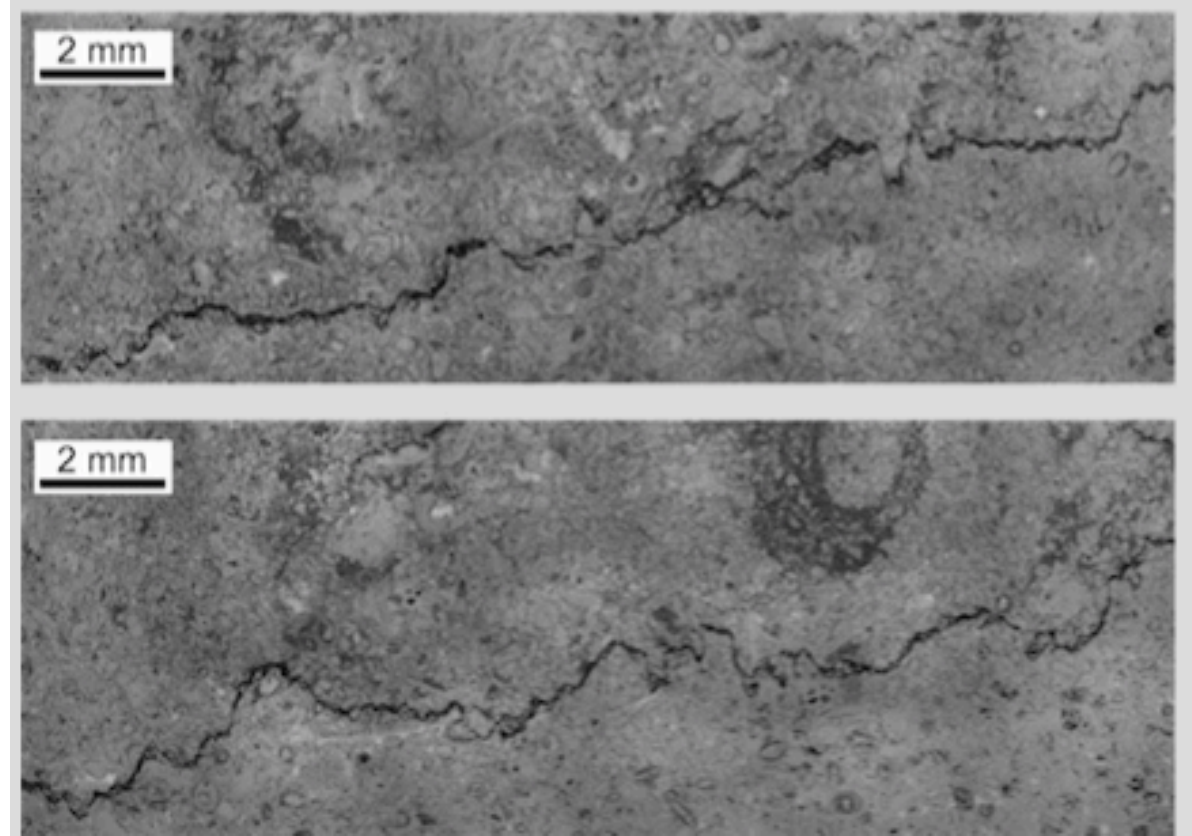
Figure 5. Optical microscope images of (a) a sedimentary stylolite and (b) a tectonic stylolite in 509 sample 03 - Oxfordian limestone from Bure.

510

\section{a) O3 Oxfordian - sedimentary stylolite}

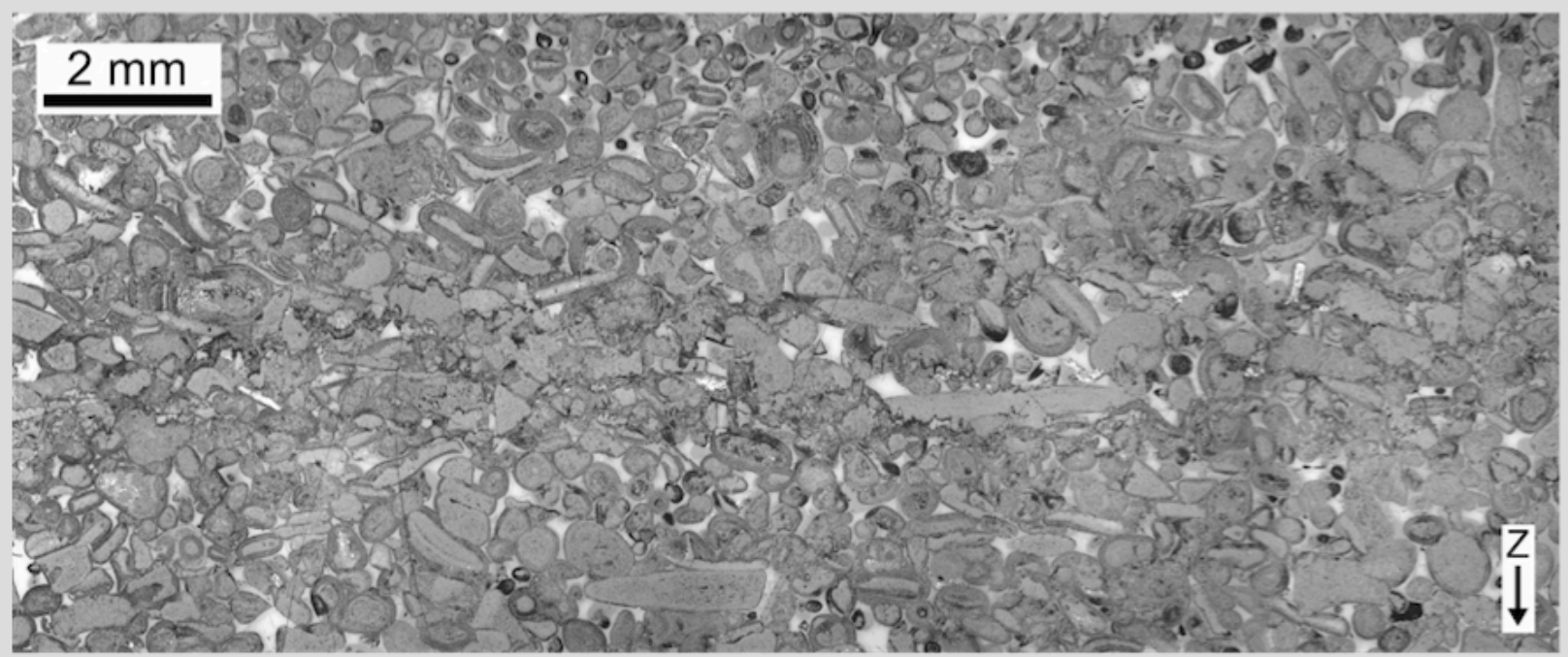

\section{b) O3 Oxfordian - tectonic stylolite}

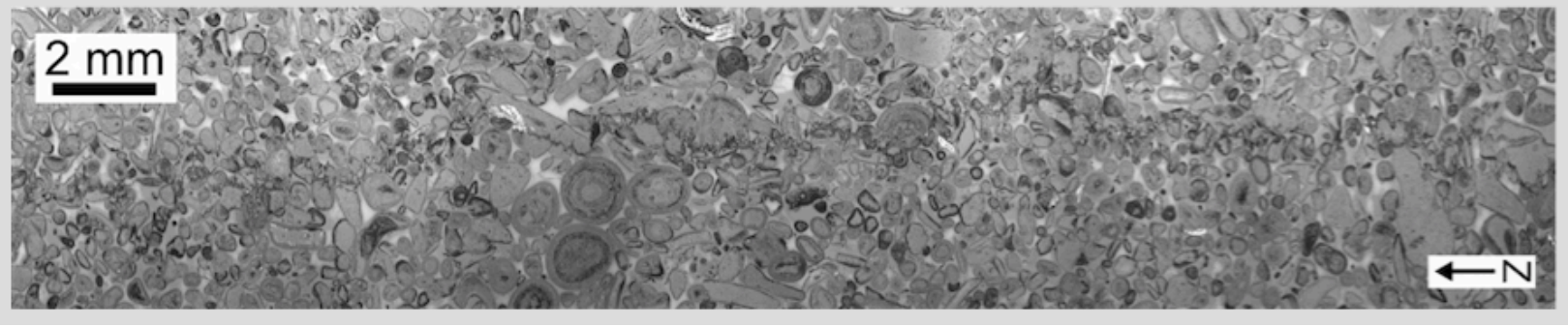


514 Figure 6. Photographs of the cylindrical samples prepared for laboratory measurements. Three 515 representative samples are shown for each lithology: an intact sample (on the left), a sample with a 516 stylolite perpendicular to flow (in the middle), and a sample with a stylolite parallel to flow (on the 517 right). (a) Sample 01 - Oxfordian limestone from Bure. (b) Sample 03 - Oxfordian limestone from 518 Bure. (c) Sample 06 - Oxfordian limestone from Bure. (d) Sample D3 - "Dogger" limestone from 519 Bure.

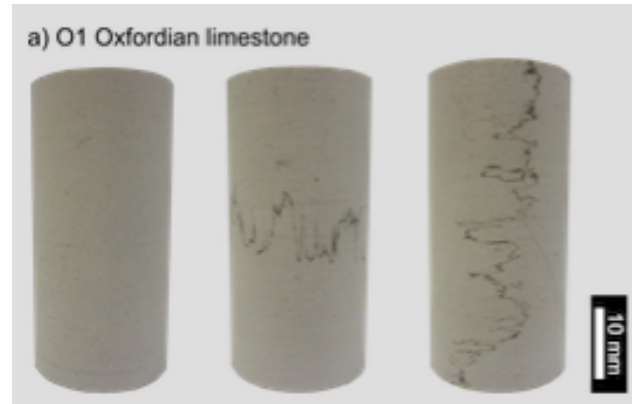

b) $\mathrm{O} 3$ Oxfordian limestone

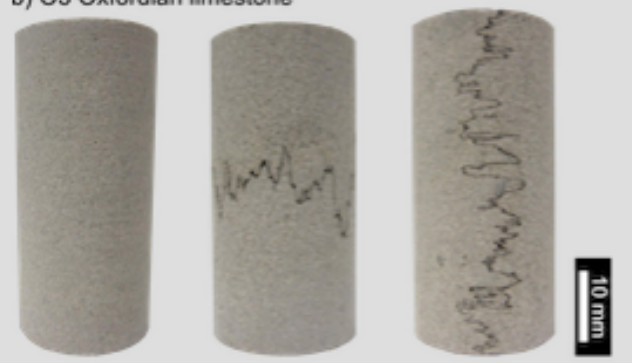

c) O6 Oxfordian limestone

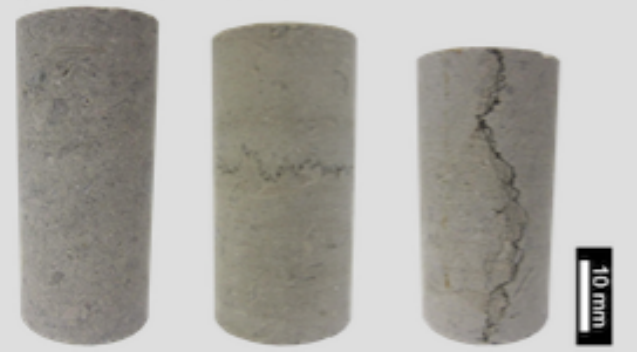

d) D3 "Dogger" limestone 
521 Figure 7. Photographs of the cylindrical samples prepared for laboratory measurements. Three

522 representative samples are shown for each lithology: an intact sample (on the left), a sample with a

523 stylolite perpendicular to flow (in the middle), and a sample with a stylolite parallel to flow (on the

524 right). (a) Corton limestone from Burgundy. (b) Comblanchien limestone from Burgundy.

525

\section{a) Comblanchien limestone}
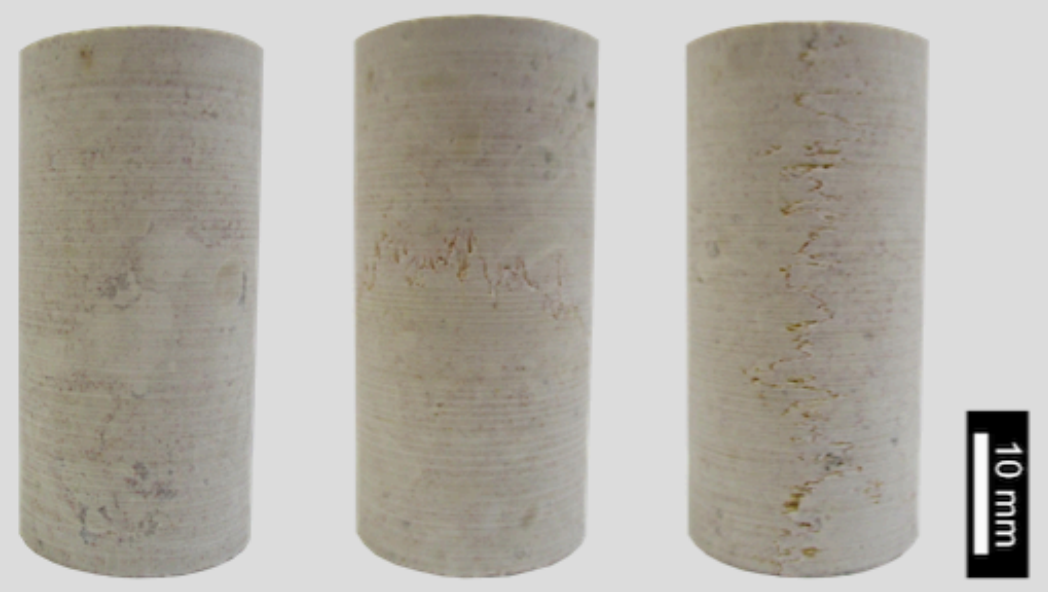

b) Corton limestone

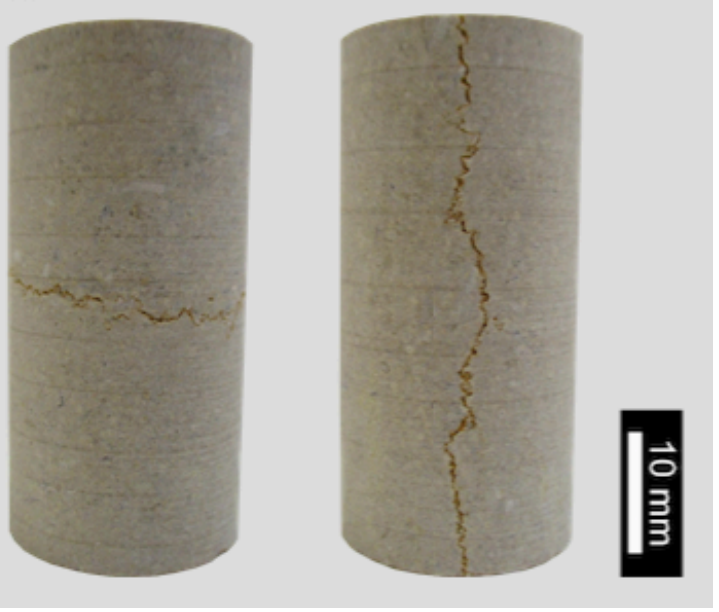


528 Figure 8. Photographs of the cylindrical samples containing either a tectonic stylolite (the two 529 samples on the left) or a sedimentary stylolite (the two samples on the right). All samples are from 530 sample 03 - Oxfordian limestone from Bure.

531

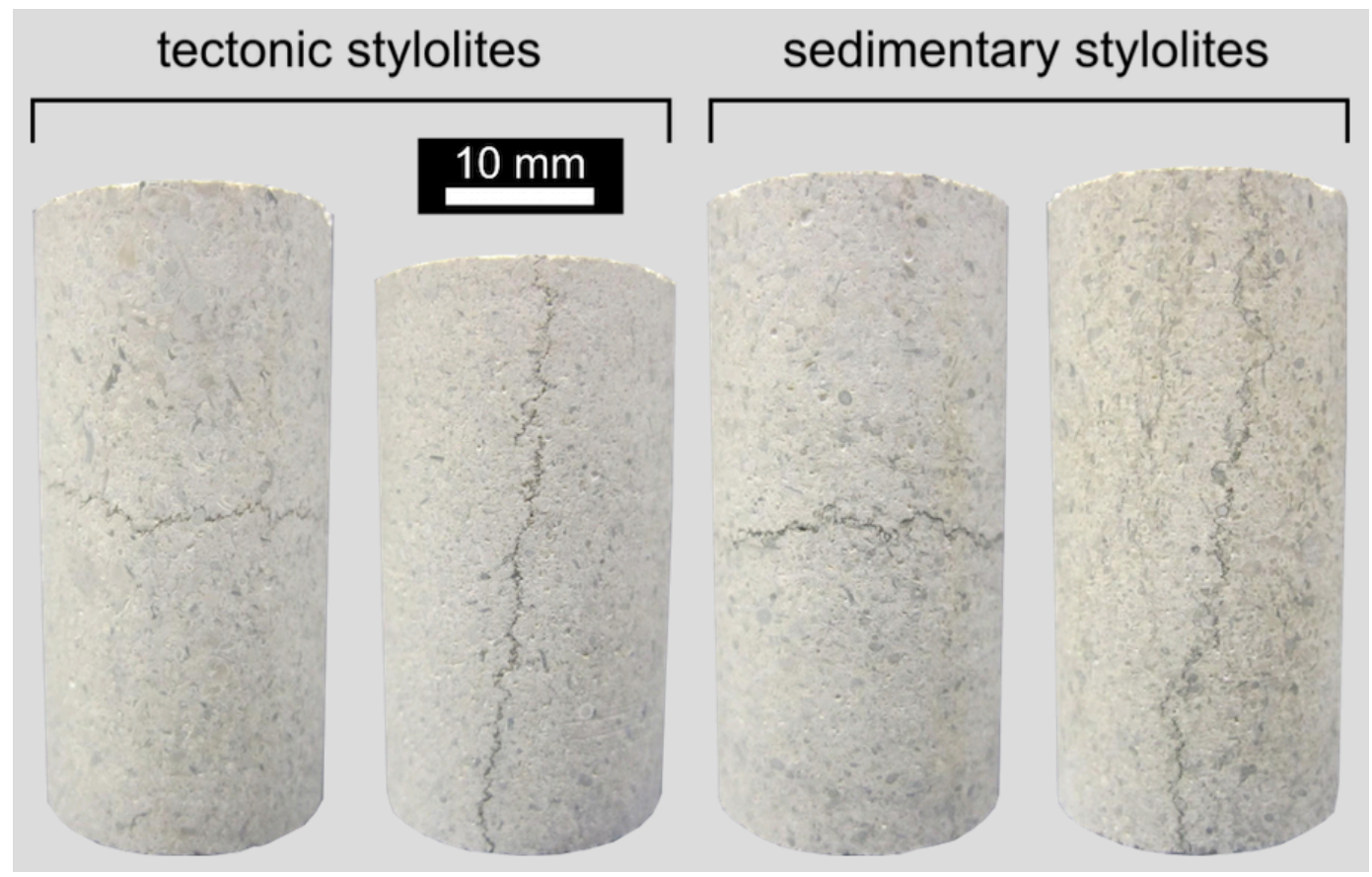


Figure 9. (a) Gas permeability (measured under a confining pressure of $2 \mathrm{MPa}$ ) as a function of 536 connected porosity for intact (i.e. stylolite-free) limestone. All datapoints above a porosity of 0.2 are 537 taken from Lind et al. (1994). (b) Gas permeability (measured under a confining pressure of $2 \mathrm{MPa}$ ) 538 as a function of connected porosity for limestone samples containing either a stylolite parallel to 539 flow or a stylolite perpendicular to flow. The gas permeabilities of the intact samples (i.e. the data of 540 panel (a)) are also plotted in panel (b).

541
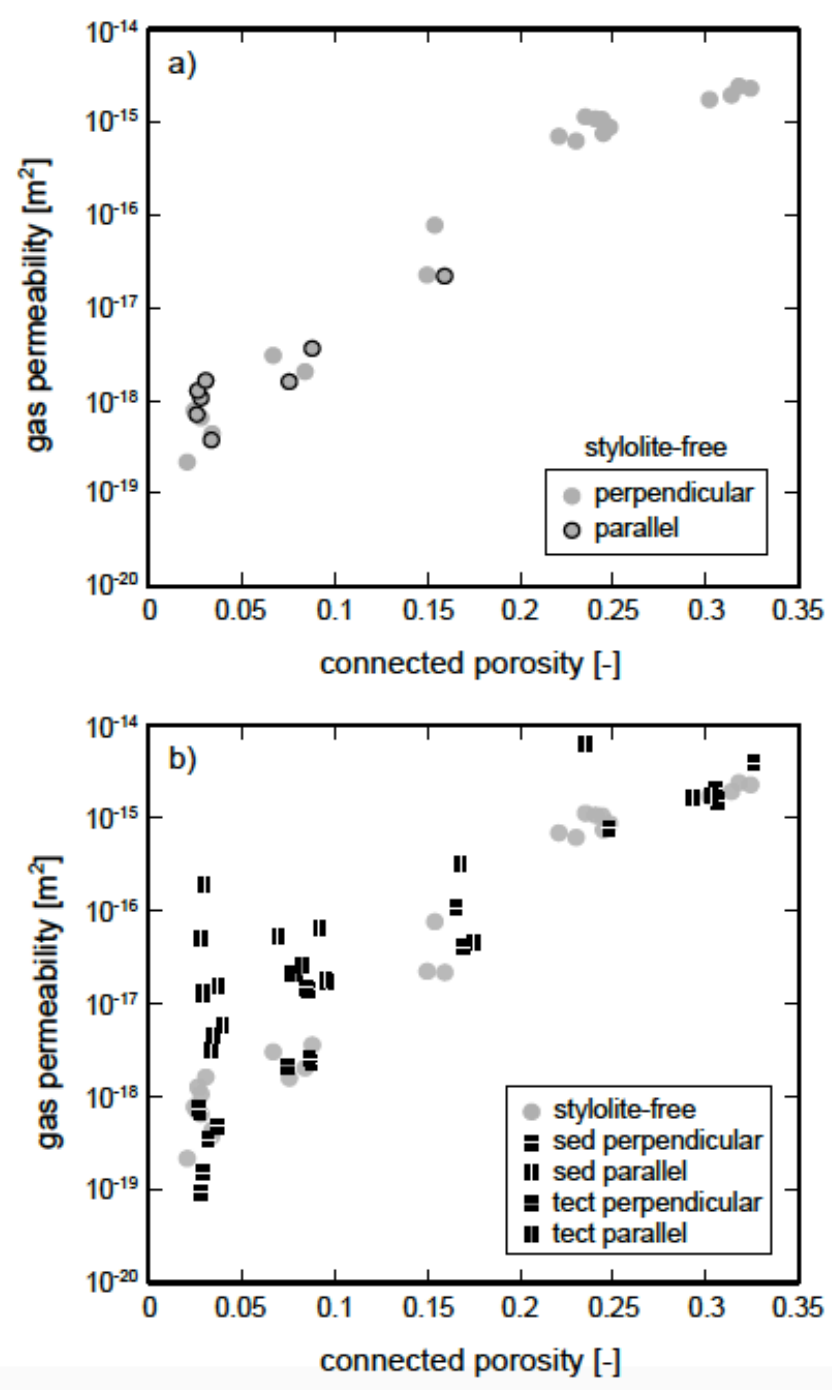
544 Figure 10. (a) The ratio of gas to water permeability as a function of connected porosity for intact

545 (i.e. stylolite-free) limestone. (b) The ratio of gas to water permeability as a function of connected 546 porosity for limestone samples containing either a stylolite parallel to flow or a stylolite

547 perpendicular to flow. The ratios of the intact samples (i.e. the data of panel (a)) are also plotted in 548 panel (b).

549
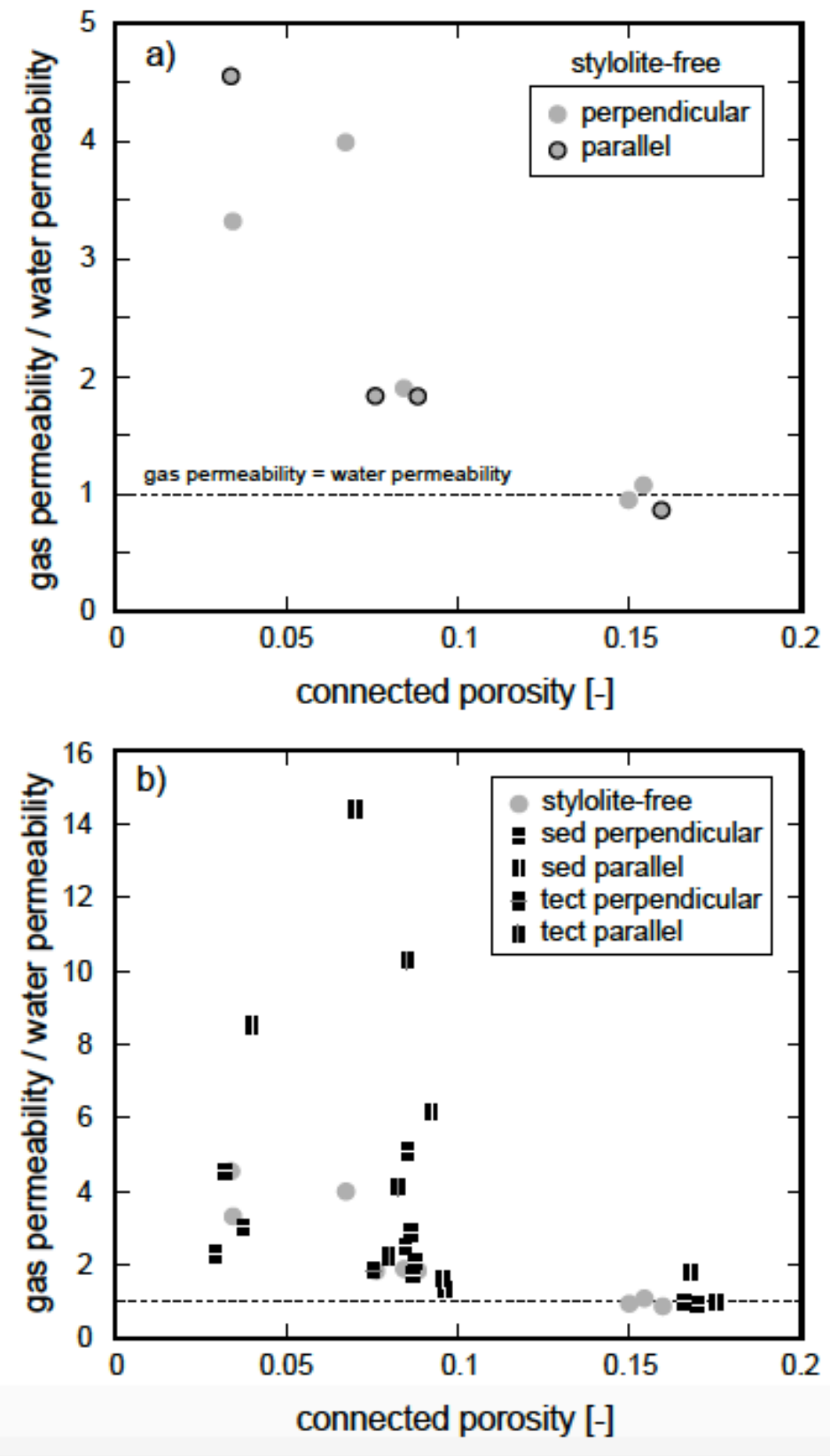
551 Figure 11. Backscattered scanning electron microscope image of the stylolite-host rock boundary

552 (sample D3 - "Dogger" limestone from Bure). Quartz grains within the stylolite are labelled. The

553 white arrows point to porosity (in black).

554

555

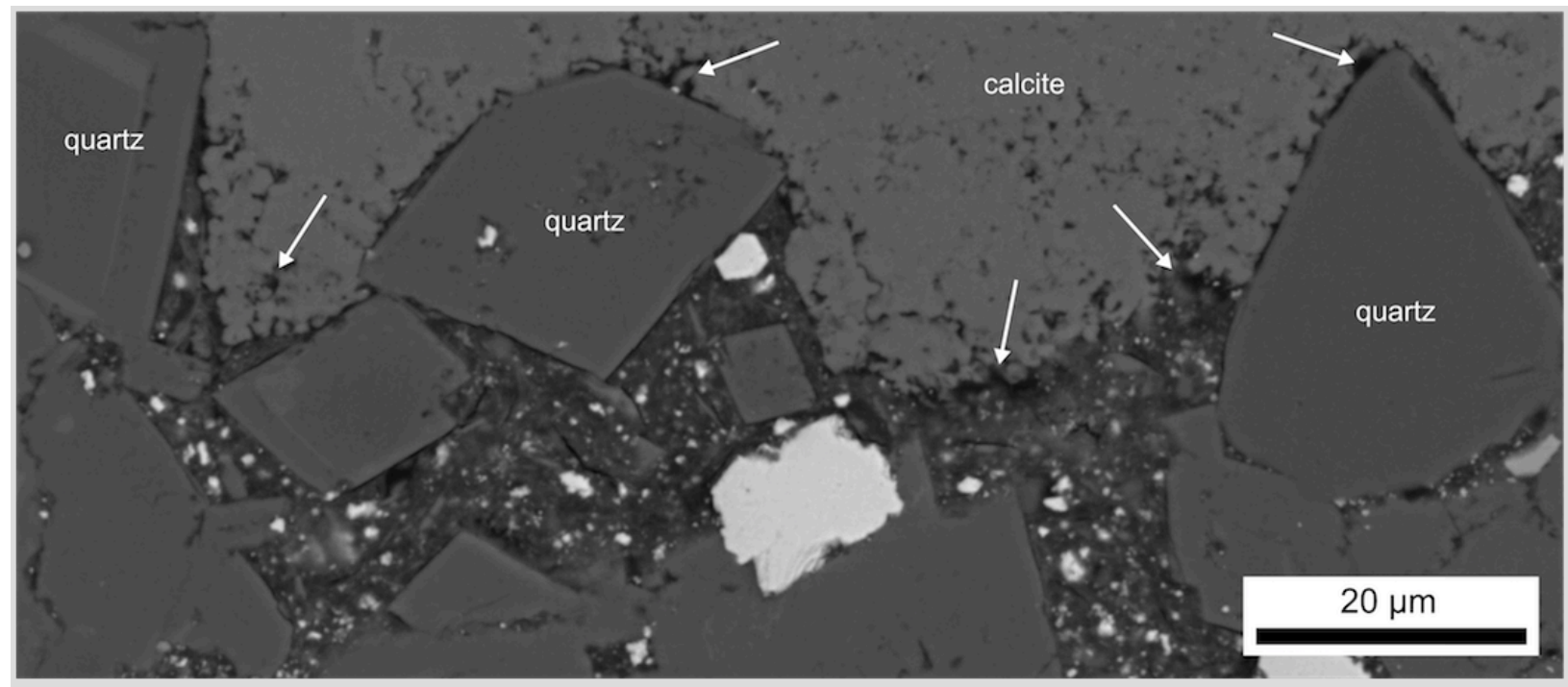

556

557 
Figure 12. Multi-resolution X-ray synchrotron microtomography images of a stylolite in sample D3

559 ("Dogger" limestone from Bure). (a) An image of the stylolite at a voxel size of $6.27 \mu \mathrm{m}$. The 560 coloured shapes are pores; individual pores are allocated different colours. (b) An image of the 561 stylolite at a voxel size of $0.7 \mu \mathrm{m}$. The coloured shapes are pores; individual pores are allocated 562 different colours.

563
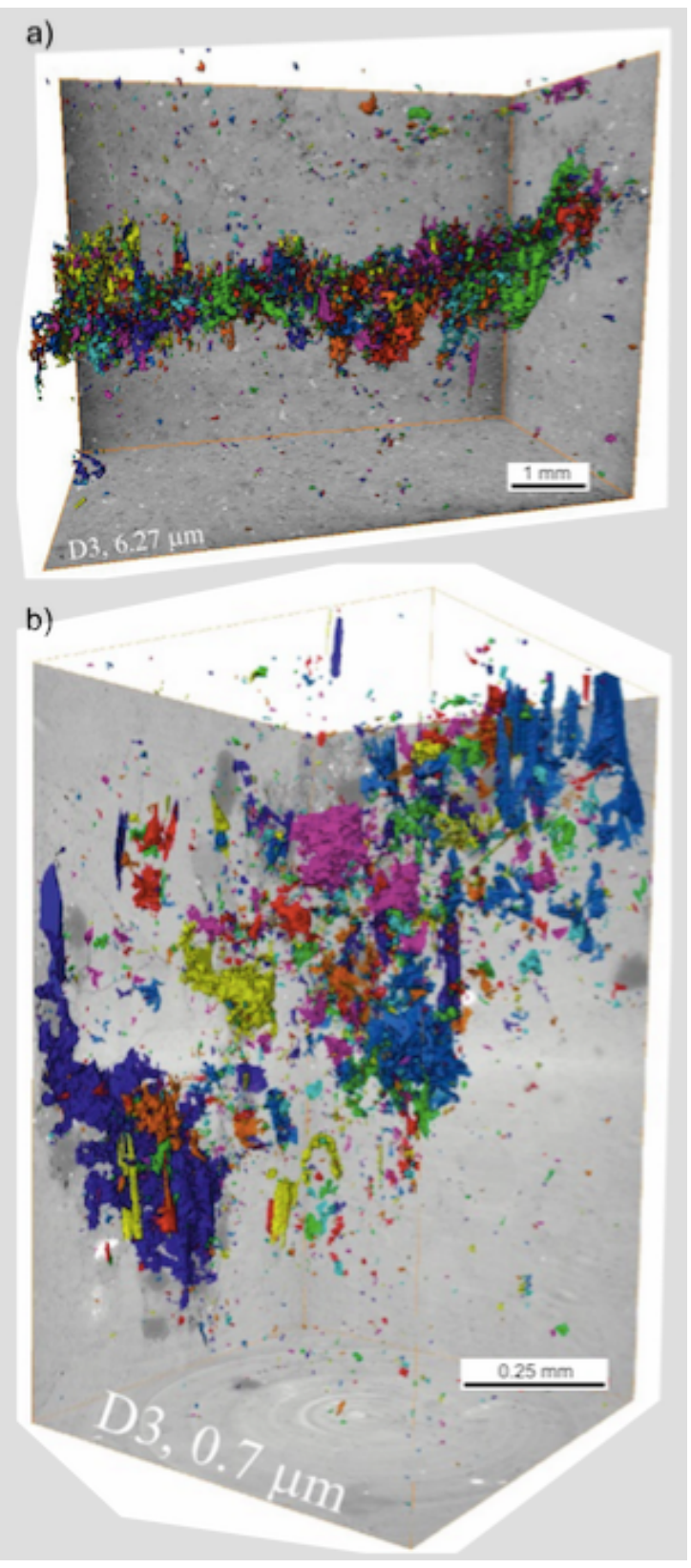
565 Figure 13. X-ray synchrotron microtomography image showing two pores within a stylolite in 566 sample D3 ("Dogger" limestone from Bure). The pores are "finger-like" in shape and are aligned 567 with the teeth of the stylolite.

568

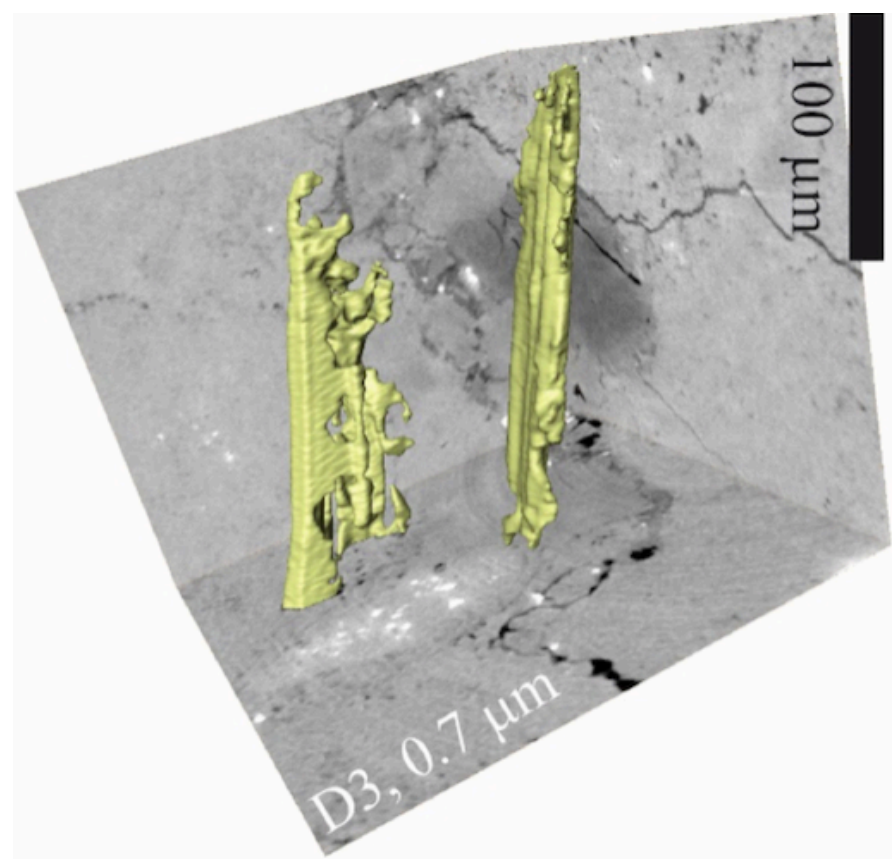

570

571 
572 Figure 14. X-ray synchrotron microtomography data showing (a) the number of pores within a 573 subvolume of $0.16 \mathrm{~mm}^{3}$ as a function of pore size inside and outside of a stylolite (sample D3 574 "Dogger" limestone from Bure) and (b) the probability density function as a function of sphericity

575 for the pores inside and outside of a stylolite (sample D3 - "Dogger" limestone from Bure). Two 576 subvolumes of sample D3 with the same volume of $0.16 \mathrm{~mm}^{3}$, one inside the stylolite and one 577 outside of it, were used to perform these calculations.

578
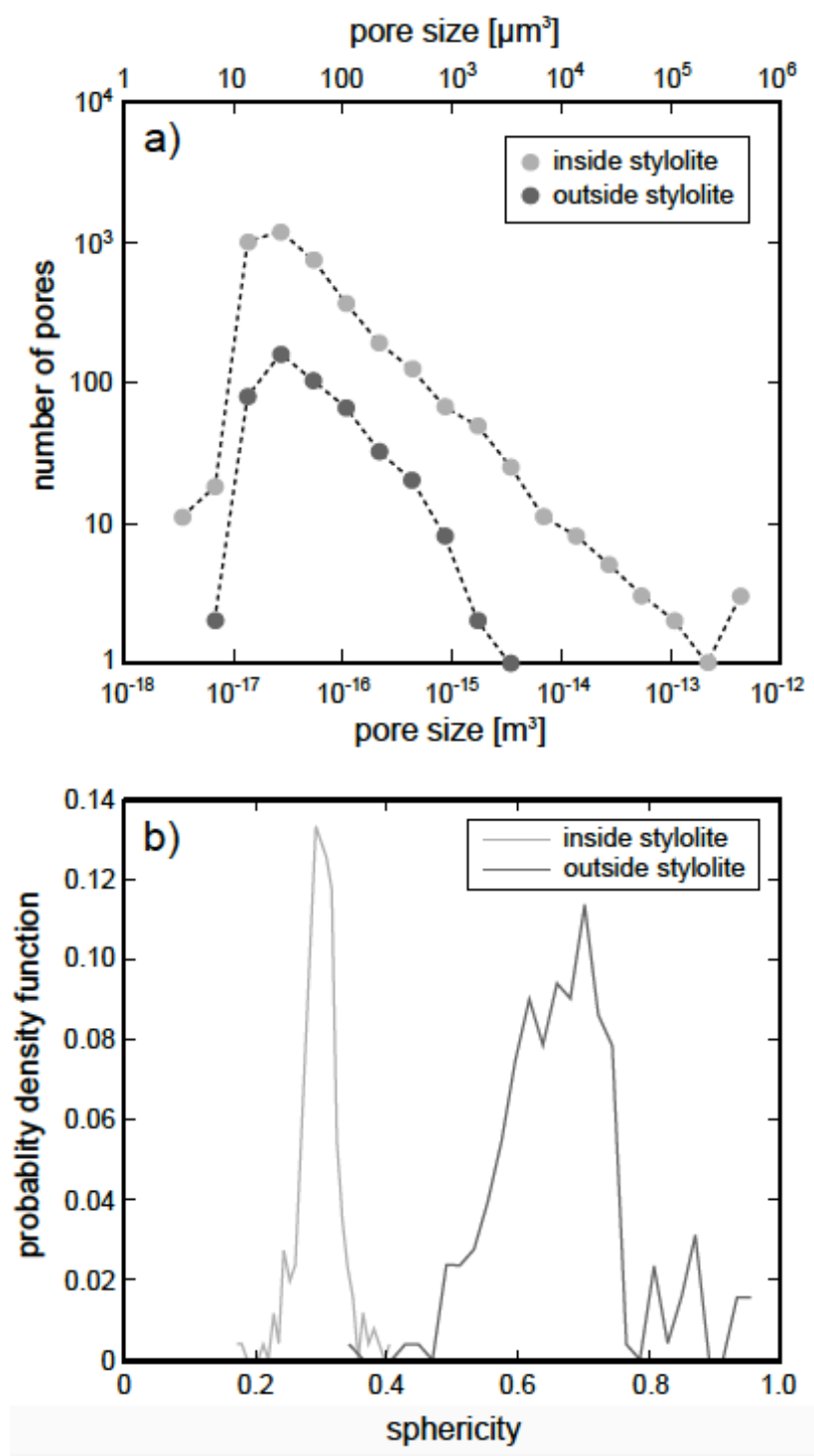
581 Figure 15. (a) The average pore radius of the flow path followed by the gas molecules (calculated 582 using the Klinkenberg slip factor; see Equation 5) as a function of connected porosity for the intact 583 (i.e. stylolite-free) samples. (a) The average pore radius of the pores used by the gas particles 584 (calculated using the Klinkenberg slip factor; see Equation 5) as a function of connected porosity for 585 limestone samples containing either a stylolite parallel to flow or a stylolite perpendicular to flow. 586 The average pore radius of the intact samples (i.e. the data of panel (a)) are also plotted in panel 587 (b).

588
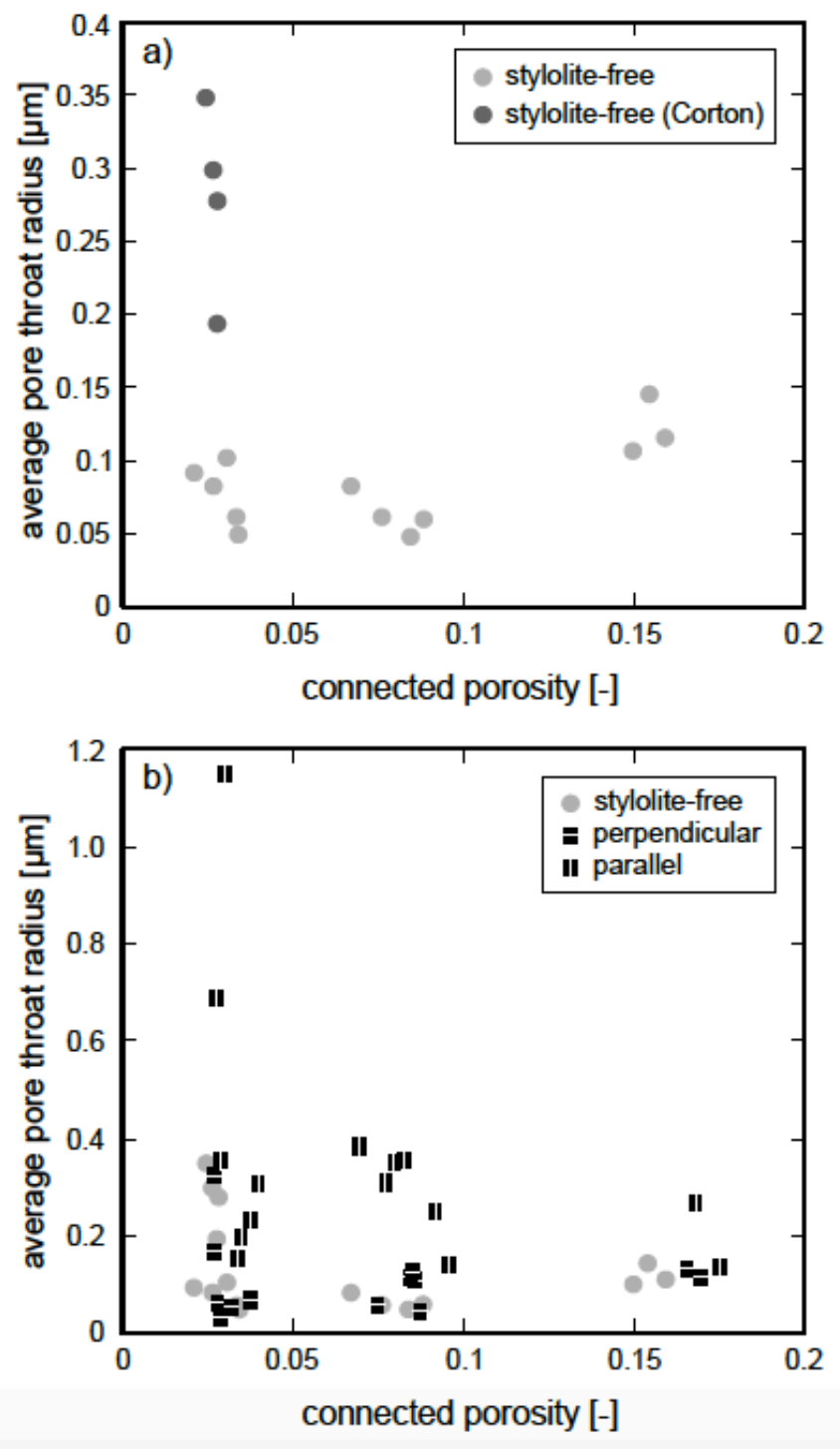
590 Figure 16. A photograph of a $78 \mathrm{~mm}$-diameter core from Bure (sample D3 - "Dogger" limestone 591 from Bure). Arrows indicate the position of sedimentary stylolites.

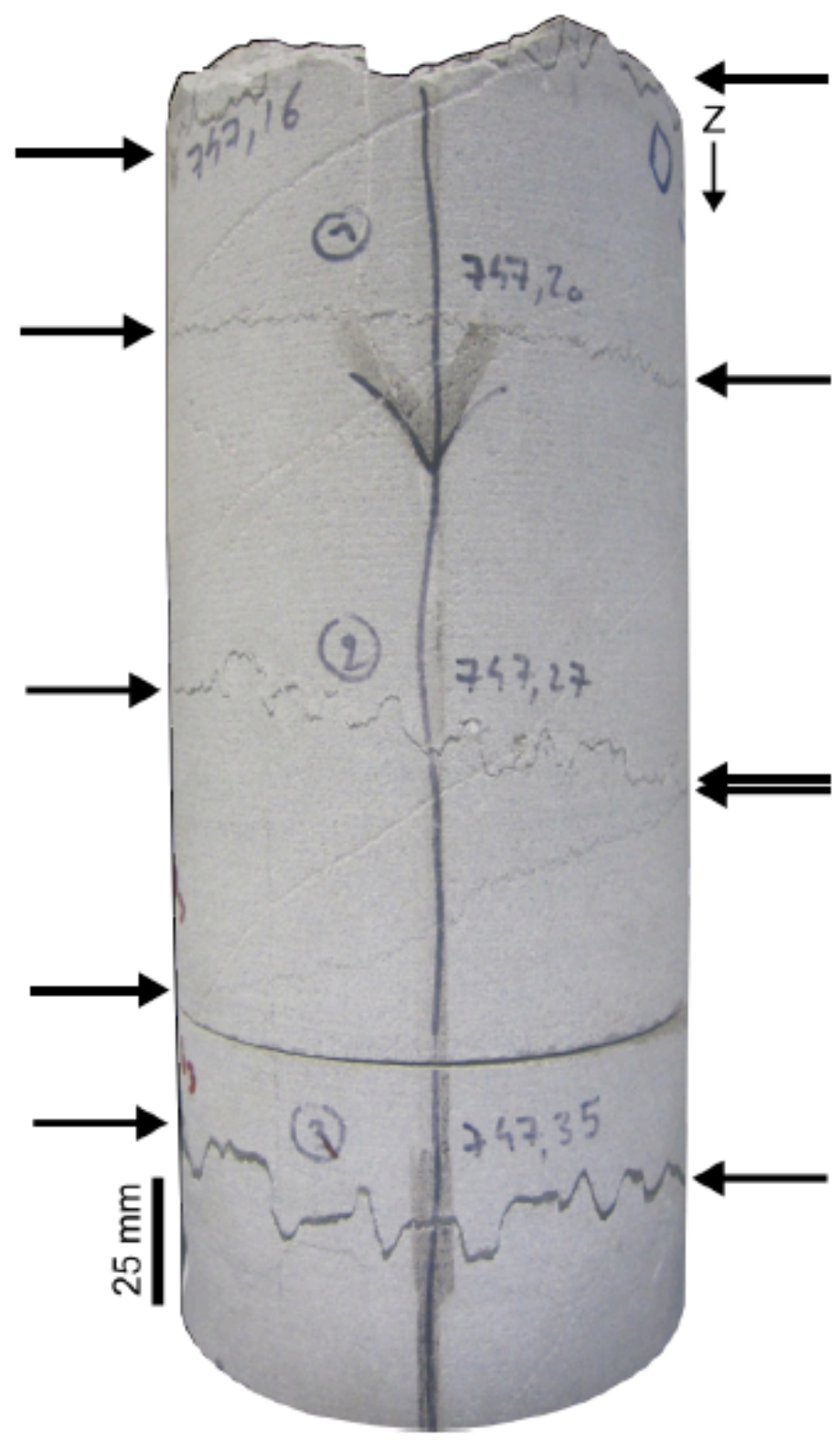


Table 1. X-ray powder diffraction (XRPD) analysis showing quantitative mineral composition for 596 the six limestones studied herein. Mineral contents of 01, 03, 06, and D3 were taken from Heap et 597 al. (2014).

\begin{tabular}{|c|c|c|}
\hline Sample & $\begin{array}{c}\text { Stylolite-free composition } \\
\text { (wt. \%) }\end{array}$ & Minerals within the stylolite \\
\hline 01 (Oxfordian limestone) & $99 \%$ calcite; $<1 \%$ dolomite & dolomite, clay \\
\hline 03 (Oxfordian limestone) & $99 \%$ calcite, $<1 \%$ dolomite; & dolomite, gypsum, pyrite, clay \\
& $<1 \%$ gypsum; $<<1 \%$ pyrite & \\
\hline 06 (Oxfordian limestone) & $99 \%$ calcite, $<1 \%$ dolomite; & dolomite, pyrite, clay \\
\hline D3 ("Dogger" limestone) & $93 \%$ quartz; $4 \%$ dolomite; $3 \%$ & dolomite, quartz, pyrite, clay \\
\hline Corton limestone & $99 \%$ calcite; $<1 \%$ quartz & quartz, clay \\
\hline Comblanchien limestone & $99 \%$ calcite & clay \\
\hline
\end{tabular}


Table 2. Summary of the experimental data collected for this study. Porosities were measured

601 using the triple weight water saturation technique. Gas and water permeabilities were measured

602 under a confining pressure of $2 \mathrm{MPa}$. Gas permeabilities were measured with either argon or

603 nitrogen gas. Water permeabilities were measured with deionised water. Asterisk indicates that the

604 connected porosity and the gas permeability data were taken from Heap et al. (2014).

\begin{tabular}{|c|c|c|c|c|c|c|}
\hline Sample & Description & $\begin{array}{c}\text { Connected } \\
\text { porosity }\end{array}$ & $\begin{array}{c}\text { Gas } \\
\text { permeability } \\
(\mathrm{m} 2)\end{array}$ & $\begin{array}{l}\text { Klinkenberg } \\
\text { slip factor } \\
\text { (MPa) }\end{array}$ & $\begin{array}{c}\text { Water } \\
\text { permeability } \\
\text { (m2) }\end{array}$ & $\begin{array}{c}\text { Gas/water } \\
\text { permeability }\end{array}$ \\
\hline${ }^{*} 01$ & $\begin{array}{l}\text { No stylo } \\
\text { perp }\end{array}$ & 0.154 & $7.77 \times 10^{-17}$ & 0.189 & $7.22 \times 10^{-17}$ & 1.08 \\
\hline${ }^{*} 01$ & $\begin{array}{c}\text { Sed stylo } \\
\text { para }\end{array}$ & 0.168 & $3.29 \times 10^{-16}$ & 0.102 & $1.81 \times 10^{-16}$ & 1.82 \\
\hline *01 & $\begin{array}{c}\text { Sed stylo } \\
\text { perp }\end{array}$ & 0.166 & $1.09 \times 10^{-16}$ & 0.206 & $1.07 \times 10^{-16}$ & 1.02 \\
\hline${ }^{*} \mathrm{O} 3$ & $\begin{array}{l}\text { No stylo } \\
\text { perp }\end{array}$ & 0.150 & $2.25 \times 10^{-17}$ & 0.309 & $2.37 \times 10^{-17}$ & 0.95 \\
\hline${ }^{*} 03$ & No stylo para & 0.159 & $2.20 \times 10^{-17}$ & 0.286 & $2.54 \times 10^{-17}$ & 0.87 \\
\hline *03 & $\begin{array}{l}\text { Sed stylo } \\
\text { perp }\end{array}$ & 0.169 & $4.10 \times 10^{-17}$ & 0.278 & $4.51 \times 10^{-17}$ & 0.91 \\
\hline$* 03$ & $\begin{array}{l}\text { Sed stylo } \\
\text { para }\end{array}$ & 0.175 & $4.65 \times 10^{-17}$ & 0.233 & $4.78 \times 10^{-17}$ & 0.97 \\
\hline 03 & No stylo para & 0.076 & $1.60 \times 10^{-18}$ & 0.449 & $8.72 \times 10^{-19}$ & 1.83 \\
\hline 03 & No stylo para & 0.088 & $3.63 \times 10^{-18}$ & 0.458 & $1.98 \times 10^{-18}$ & 1.83 \\
\hline 03 & $\begin{array}{l}\text { No stylo } \\
\text { perp }\end{array}$ & 0.084 & $2.05 \times 10^{-18}$ & 0.568 & $1.08 \times 10^{-18}$ & 1.90 \\
\hline 03 & $\begin{array}{l}\text { Tect stylo } \\
\text { perp }\end{array}$ & 0.075 & $2.14 \times 10^{-18}$ & 0.452 & $1.16 \times 10^{-18}$ & 1.84 \\
\hline 03 & $\begin{array}{l}\text { Tect stylo } \\
\text { para }\end{array}$ & 0.080 & $2.18 \times 10^{-17}$ & 0.079 & $9.73 \times 10^{-18}$ & 2.24 \\
\hline 03 & $\begin{array}{c}\text { Tect stylo } \\
\text { para }\end{array}$ & 0.082 & $2.62 \times 10^{-17}$ & 0.078 & $6.35 \times 10^{-18}$ & 4.13 \\
\hline 03 & $\begin{array}{c}\text { Tect stylo } \\
\text { para }\end{array}$ & 0.077 & $2.17 \times 10^{-17}$ & 0.089 & $7.17 \times 10^{-18}$ & 3.03 \\
\hline 03 & $\begin{array}{l}\text { Sed stylo } \\
\text { perp }\end{array}$ & 0.087 & $2.32 \times 10^{-18}$ & 0.621 & $1.12 \times 10^{-18}$ & 2.07 \\
\hline 03 & $\begin{array}{l}\text { Sed stylo } \\
\text { perp }\end{array}$ & 0.087 & $2.61 \times 10^{-18}$ & 0.537 & $1.51 \times 10^{-18}$ & 1.73 \\
\hline 03 & $\begin{array}{c}\text { Sed stylo } \\
\text { para }\end{array}$ & 0.096 & $1.75 \times 10^{-17}$ & 0.196 & $1.34 \times 10^{-17}$ & 1.31 \\
\hline 03 & $\begin{array}{c}\text { Sed stylo } \\
\text { para }\end{array}$ & 0.095 & $1.84 \times 10^{-17}$ & 0.195 & $1.15 \times 10^{-17}$ & 1.60 \\
\hline *06 & $\begin{array}{l}\text { No stylo } \\
\text { perp }\end{array}$ & 0.067 & $3.04 \times 10^{-18}$ & 0.335 & $7.62 \times 10^{-19}$ & 3.99 \\
\hline *06 & $\begin{array}{c}\text { Sed stylo } \\
\text { para }\end{array}$ & 0.070 & $5.36 \times 10^{-17}$ & 0.102 & $3.72 \times 10^{-18}$ & 14.41 \\
\hline *06 & $\begin{array}{l}\text { Sed stylo } \\
\text { para }\end{array}$ & 0.092 & $6.58 \times 10^{-17}$ & 0.111 & $1.07 \times 10^{-17}$ & 6.15 \\
\hline${ }^{*} 06$ & Sed stylo & 0.084 & $1.51 \times 10^{-17}$ & 0.241 & $6.04 \times 10^{-18}$ & 2.50 \\
\hline
\end{tabular}




\begin{tabular}{|c|c|c|c|c|c|c|}
\hline & perp & & & & & \\
\hline *06 & $\begin{array}{l}\text { Sed stylo } \\
\text { perp }\end{array}$ & 0.086 & $1.43 \times 10^{-17}$ & 0.252 & $4.98 \times 10^{-18}$ & 2.87 \\
\hline *06 & $\begin{array}{l}\text { Sed stylo } \\
\text { perp }\end{array}$ & 0.085 & $1.39 \times 10^{-17}$ & 0.217 & $2.73 \times 10^{-18}$ & 5.09 \\
\hline *D3 & $\begin{array}{l}\text { No stylo } \\
\text { perp }\end{array}$ & 0.034 & $4.38 \times 10^{-19}$ & 0.557 & $1.32 \times 10^{-19}$ & 3.32 \\
\hline *D3 & No stylo para & 0.034 & $3.69 \times 10^{-19}$ & 0.447 & $8.11 \times 10^{-20}$ & 4.55 \\
\hline *D3 & $\begin{array}{l}\text { Sed stylo } \\
\text { perp }\end{array}$ & 0.037 & $4.88 \times 10^{-19}$ & 0.398 & $1.61 \times 10^{-19}$ & 3.03 \\
\hline *D3 & $\begin{array}{l}\text { Sed stylo } \\
\text { perp }\end{array}$ & 0.032 & $3.44 \times 10^{-19}$ & 0.521 & $7.55 \times 10^{-20}$ & 4.56 \\
\hline *D3 & $\begin{array}{l}\text { Sed stylo } \\
\text { perp }\end{array}$ & 0.029 & $1.56 \times 10^{-19}$ & 0.847 & $6.83 \times 10^{-20}$ & 2.28 \\
\hline *D3 & $\begin{array}{c}\text { Sed stylo } \\
\text { para }\end{array}$ & 0.040 & $5.98 \times 10^{-18}$ & 0.089 & $7.01 \times 10^{-19}$ & 8.53 \\
\hline COMB & No stylo para & 0.031 & $1.64 \times 10^{-18}$ & 0.270 & - & - \\
\hline COMB & No stylo para & 0.026 & $7.20 \times 10^{-19}$ & 0.335 & - & - \\
\hline $\mathrm{COMB}$ & $\begin{array}{c}\text { Sed stylo } \\
\text { para }\end{array}$ & 0.037 & $1.54 \times 10^{-17}$ & 0.118 & - & - \\
\hline $\mathrm{COMB}$ & $\begin{array}{c}\text { Sed stylo } \\
\text { para }\end{array}$ & 0.034 & $3.20 \times 10^{-18}$ & 0.180 & - & - \\
\hline COMB & $\begin{array}{c}\text { Sed stylo } \\
\text { para }\end{array}$ & 0.035 & $4.64 \times 10^{-18}$ & 0.140 & - & - \\
\hline COMB & $\begin{array}{c}\text { No stylo } \\
\text { perp }\end{array}$ & 0.021 & $2.18 \times 10^{-19}$ & 0.298 & - & - \\
\hline COMB & $\begin{array}{l}\text { Sed stylo } \\
\text { perp }\end{array}$ & 0.027 & $6.95 \times 10^{-19}$ & 0.164 & - & - \\
\hline CORT & No stylo para & 0.026 & $1.28 \times 10^{-18}$ & 0.092 & - & - \\
\hline CORT & No stylo para & 0.028 & $1.07 \times 10^{-18}$ & 0.099 & - & - \\
\hline CORT & $\begin{array}{c}\text { Sed stylo } \\
\text { para }\end{array}$ & 0.033 & $1.98 \times 10^{-16}$ & 0.024 & - & - \\
\hline CORT & $\begin{array}{c}\text { Sed stylo } \\
\text { para }\end{array}$ & 0.030 & $5.22 \times 10^{-17}$ & 0.040 & - & - \\
\hline CORT & $\begin{array}{c}\text { Sed stylo } \\
\text { para }\end{array}$ & 0.031 & $1.31 \times 10^{-17}$ & 0.078 & - & - \\
\hline CORT & $\begin{array}{l}\text { No stylo } \\
\text { perp }\end{array}$ & 0.026 & $7.85 \times 10^{-19}$ & 0.079 & - & - \\
\hline CORT & $\begin{array}{c}\text { No stylo } \\
\text { perp }\end{array}$ & 0.029 & $6.58 \times 10^{-19}$ & 0.142 & - & - \\
\hline CORT & $\begin{array}{c}\text { Sed stylo } \\
\text { perp }\end{array}$ & 0.027 & $7.48 \times 10^{-19}$ & 0.085 & - & - \\
\hline CORT & $\begin{array}{l}\text { Sed stylo } \\
\text { perp }\end{array}$ & 0.031 & $9.45 \times 10^{-20}$ & 0.433 & - & - \\
\hline
\end{tabular}

605

606 


\section{References}

608

Agosta, F., Ruano, P., Rustichelli, A., Tondi, E., Galindo-Zaldívar, J. and de Galdeano, C.S. 2012. Inner structure and deformation mechanisms of normal faults in conglomerates and carbonate grainstones (Granada Basin, Betic Cordillera, Spain): inferences on fault permeability. Journal of Structural Geology, 45, 4-20.

Alsharhan, A., and Sadd, J.L. 2000. Stylolites in Lower Cretaceous carbonate reservoirs, U.A.E: Society for Sedimentary Geology Special Publication, 69, 185-207.

Andrews, L.M. and Railsback, L.B. 1997. Controls on stylolite development: morphologic, lithologic, and temporal evidence from bedding-parallel and transverse stylolites from the US Appalachians. The Journal of Geology, 105(1), 59-73.

Baud, P., Rolland, A., Heap, M., Xu, T., Nicolé, M., Ferrand, T., \& Conil, N. 2016. Impact of stylolites on the mechanical strength of limestone. Tectonophysics, 690, 4-20.

Behnsen, J., \& Faulkner, D. R. 2011. Water and argon permeability of phyllosilicate powders under medium to high pressure. Journal of Geophysical Research: Solid Earth, 116(B12), B12203, doi:10.1029/2011JB008600

Benedicto, A., \& Schultz, R. A. 2010. Stylolites in limestone: magnitude of contractional strain accommodated and scaling relationships. Journal of Structural Geology, 32(9), 1250-1256.

Bjørkum, P.A., Oelkers, E.H., Nadeau, P.H., Walderhaug, O. and Murphy, W.M. 1998. Porosity prediction in quartzose sandstones as a function of time, temperature, depth, stylolite frequency, and hydrocarbon saturation. AAPG bulletin, 82(4), 637-648.

Braithwaite, C. J. R. 1989. Stylolites as open fluid conduits. Marine and Petroleum Geology, 6(1), 9396.

Brouste, A., Renard, F., Gratier, J.P. and Schmittbuhl, J. 2007. Variety of stylolites' morphologies and statistical characterization of the amount of heterogeneities in the rock. Journal of Structural Geology, 29(3), 422-434.

Burgess, C. J., \& Peter, C. K. 1985. Formation, distribution, and prediction of stylolites as permeability barriers in the Thamama Group, Abu Dhabi. In Middle East Oil Technical Conference and Exhibition. Society of Petroleum Engineers.

Brace, W., Walsh, J. B., \& Frangos, W. T. 1968. Permeability of granite under high pressure. Journal of Geophysical research, 73(6), 2225-2236.

Bruna, P. O., Lavenu, A. P., Matonti, C., \& Bertotti, G. (2018). Are stylolites fluid-flow efficient features? Journal of Structural Geology, doi: 10.1016/j.jsg.2018.05.018.

Carozzi, A. V., \& Bergen, D. V. 1987. Stylolitic porosity in carbonates: a critical factor for deep hydrocarbon production. Journal of Petroleum Geology, 10(3), 267-282.

Civan, F. 2010. Effective correlation of apparent gas permeability in tight porous media. Transport in porous media, 82(2), 375-384.

Corwin, L. W., Broomhall, R. W., Saidikowski, R. M., \& Wooten, J. N. (1997). Stylolites impact the miscible nitrogen flood in a mature carbonate oil field. In: Middle East Oil Show and Conference, Society of Petroleum Engineers, doi: doi.org/10.2118/37780-MS.

Croizé, D., Renard, F. and Gratier, J.P. 2013. Compaction and porosity reduction in carbonates: A review of observations, theory, and experiments. Advances in Geophysics, 54, 181-238.

Davy, C. A., Skoczylas, F., Barnichon, J. D., \& Lebon, P. 2007. Permeability of macro-cracked argillite under confinement: gas and water testing. Physics and Chemistry of the Earth, Parts $A / B / C$, 32(8-14), 667-680.

Dunnington, H. V. 1967. Aspects of diagenesis and shape change in stylolitic limestone reservoirs. In 7th World Petroleum Congress. World Petroleum Congress. 
Dutton, S. P., \& Willis, B. J. 1998. Comparison of outcrop and subsurface sandstone permeability distribution, lower cretaceous fall river formation, South Dakota and Wyoming. Journal of Sedimentary Research, 68(5), 890-900.

Ebner, M., Koehn, D., Toussaint, R., Renard, F. and Schmittbuhl, J. 2009a. Stress sensitivity of stylolite morphology. Earth and Planetary Science Letters, 277(3), 394-398.

Ebner, M., Koehn, D., Toussaint, R. and Renard, F. 2009b. The influence of rock heterogeneity on the scaling properties of simulated and natural stylolites. Journal of Structural geology, 31(1), 7282.

Ebner, M., Piazolo, S., Renard, F. and Koehn, D. 2010a. Stylolite interfaces and surrounding matrix material: Nature and role of heterogeneities in roughness and microstructural development. Journal of Structural Geology, 32(8), 1070-1084.

Ebner, M., Toussaint, R., Schmittbuhl, J., Koehn, D. and Bons, P. 2010b. Anisotropic scaling of tectonic stylolites: A fossilized signature of the stress field?. Journal of Geophysical Research: Solid Earth, 115(B6), B06403, doi:10.1029/2009JB006649.

Emmanuel, S., Ague, J. J., \& Walderhaug, O. (2010). Interfacial energy effects and the evolution of pore size distributions during quartz precipitation in sandstone. Geochimica et Cosmochimica Acta, 74(12), 3539-3552.

Fabricius, I.L. and Borre, M.K. 2007. Stylolites, porosity, depositional texture, and silicates in chalk facies sediments. Ontong Java Plateau-Gorm and Tyra fields, North Sea. Sedimentology, 54(1), 183-205.

Farquharson, J. I., Heap, M. J., Lavallée, Y., Varley, N. R., \& Baud, P. 2016. Evidence for the development of permeability anisotropy in lava domes and volcanic conduits. Journal of Volcanology and Geothermal Research, 323, 163-185.

Faulkner, D. R., \& Rutter, E. H. 2000. Comparisons of water and argon permeability in natural claybearing fault gouge under high pressure at $20^{\circ}$ C. Journal of Geophysical Research: Solid Earth, 105(B7), 16415-16426.

Faulkner, D. R., \& Rutter, E. H. 2003. The effect of temperature, the nature of the pore fluid, and subyield differential stress on the permeability of phyllosilicate-rich fault gouge. Journal of Geophysical Research: Solid Earth, 108(B5), 2227, doi:10.1029/2001JB001581.

Finkel, E. A., \& Wilkinson, B. H. 1990. Stylolitization as Source of Cement in Mississippian Salem Limestone, West-Central Indiana (1). AAPG Bulletin, 74(2), 174-186.

Firouzi, M., Alnoaimi, K., Kovscek, A., \& Wilcox, J. 2014. Klinkenberg effect on predicting and measuring helium permeability in gas shales. International Journal of Coal Geology, 123, 6268.

Forchheimer, P. (1901). Wasserbewegung durch boden. Z. Ver. Deutsch, Ing., 45, 1782-1788.

Ford, D., \& Williams, P. D. 2013. Karst Hydrogeology and Geomorphology. John Wiley \& Sons.

Gingras, M. K., MaCmillan, B., \& Balcom, B. J. 2002. Visualizing the internal physical characteristics of carbonate sediments with magnetic resonance imaging and petrography. Bulletin of Canadian Petroleum Geology, 50(3), 363-369.

Heald, M.T., 1955. Stylolites in sandstones. The Journal of Geology, 63(2), 101-114.

Heap, M.J., Baud, P., Reuschlé, T. and Meredith, P.G. 2014. Stylolites in limestones: Barriers to fluid flow?. Geology, 42(1), 51-54.

Heap, M. J., \& Kennedy, B. M. 2016. Exploring the scale-dependent permeability of fractured andesite. Earth and Planetary Science Letters, 447, 139-150.

Heap, M. J., Kushnir, A. R., Gilg, H. A., Wadsworth, F. B., Reuschlé, T., \& Baud, P. 2017. Microstructural and petrophysical properties of the Permo-Triassic sandstones (Buntsandstein) from the Soultz-sous-Forêts geothermal site (France). Geothermal Energy, 5(1), 26.

Heap, M. J., Reuschlé, T., Farquharson, J. I., \& Baud, P. 2018. Permeability of volcanic rocks to gas and water. Journal of Volcanology and Geothermal Research, 354, 29-38. 
Heller, R., Vermylen, J., \& Zoback, M. 2014. Experimental investigation of matrix permeability of gas shales. AAPG Bulletin, 98(5), 975-995.

Iezzi, G., Ventura, G. D., Oberti, R., Cámara, F., \& Holtz, F. 2004. Synthesis and crystal-chemistry of Na (NaMg) Mg5Si8O22 (OH) 2, a P 21/m amphibole. American Mineralogist, 89(4), 640-646.

Iezzi, G., Della Ventura, G., Tribaudino, M., Nemeth, P., Margiolaki, I., Cavallo, A.,. \& Behrens, H. 2010. Phase transition induced by solid solution: The ${ }^{\mathrm{B}} \mathrm{Ca}-{ }^{\mathrm{B}} \mathrm{Mg}$ substitution in richteritic amphiboles. American Mineralogist, 95(2-3), 369-381.

Ji, Y., Baud, P., Vajdova, V., \& Wong, T.-f. 2012. Characterization of pore geometry of Indiana limestone in relation to mechanical compaction. Oil \& Gas Science and Technology-Revue d'IFP Energies Nouvelles, 67(5), 753-775.

Ji, Y., Hall, S. A., Baud, P., \& Wong, T.-f. 2014. Characterization of pore structure and strain localization in Majella limestone by X-ray computed tomography and digital image correlation. Geophysical Journal International, 200(2), 701-719.

Karcz, Z. and Scholz, C.H. 2003. The fractal geometry of some stylolites from the Calcare Massiccio Formation, Italy. Journal of Structural Geology, 25(8), 1301-1316.

Klinkenberg, L. J. (1941). The permeability of porous media to liquids and gases. In Drilling and production practice. American Petroleum Institute.

Koehn, D., Renard, F., Toussaint, R. and Passchier, C.W. 2007. Growth of stylolite teeth patterns depending on normal stress and finite compaction. Earth and Planetary Science Letters, 257(3), 582-595.

Koehn, D., Ebner, M., Renard, F., Toussaint, R. and Passchier, C.W. 2012. Modelling of stylolite geometries and stress scaling. Earth and Planetary Science Letters, 341, 104-113.

Koehn, D., Rood, M. P., Beaudoin, N., Chung, P., Bons, P. D., \& Gomez-Rivas, E. 2016. A new stylolite classification scheme to estimate compaction and local permeability variations. Sedimentary Geology, 346, 60-71.

Koepnick, R. B. 1987. Distribution and permeability of stylolite-bearing horizons within a Lower Cretaceous carbonate reservoir in the Middle East. SPE Formation Evaluation, 2(02), 137-142.

Kushnir, A. R., Heap, M. J., \& Baud, P. 2018. Assessing the role of fractures on the permeability of the Permo-Triassic sandstones at the Soultz-sous-Forêts (France) geothermal site. Geothermics, 74, 181-189.

Laronne Ben-Itzhak, L.L., Aharonov, E., Toussaint, R. and Sagy, A. 2012. Upper bound on stylolite roughness as indicator for amount of dissolution. Earth and Planetary Science Letters, 337, 186-196.

Laronne Ben-Itzhak, L.L., Aharonov, E., Karcz, Z., Kaduri, M. and Toussaint, R. 2014. Sedimentary stylolite networks and connectivity in Limestone: Large-scale field observations and implications for structure evolution. Journal of Structural Geology, 63, 106-123.

Larson, A. C., \& Von Dreele, R. B. 1994. GSAS. Report lAUR, 86-748.

Letham, E. A., \& Bustin, R. M. 2016. The impact of gas slippage on permeability effective stress laws: Implications for predicting permeability of fine-grained lithologies. International Journal of Coal Geology, 167, 93-102.

Lind, I., Nykjaer, O., Priisholm, S. and Springer, N. 1994. Permeability of stylolite-bearing chalk. Journal of Petroleum Technology, 46(11), 986-993.

Mallon, A.J. and Swarbrick, R.E. 2008. Diagenetic characteristics of low permeability, non-reservoir chalks from the Central North Sea. Marine and Petroleum Geology, 25(10), 1097-1108.

Martín-Martín, J. D., Gomez-Rivas, E., Gómez-Gras, D., Travé, A., Ameneiro, R., Koehn, D., \& Bons, P. D. 2018. Activation of stylolites as conduits for overpressured fluid flow in dolomitized platform carbonates. Geological Society, London, Special Publications, 459(1), 157-176.

Nelson, R. A. 1981. Significance of fracture sets associated with stylolite zones: geologic notes. AAPG Bulletin, 65(11), 2417-2425. 
Nenna, F. and Aydin, A. 2011. The formation and growth of pressure solution seams in clastic rocks: A field and analytical study. Journal of Structural Geology, 33(4), 633-643.

Padmanabhan, E., Sivapriya, B., Huang, K. H., Askury, A. K., \& Chow, W. S. 2015. The impact of stylolites and fractures in defining critical petrophysical and geomechanical properties of some carbonate rocks. Geomechanics and Geophysics for Geo-Energy and Geo-Resources, 1(12), 55-67.

Park, W.C. and Schot, E.H. 1968. Stylolites: their nature and origin. Journal of Sedimentary Research, 38(1), 175-191.

Railsback, L.B. and Andrews, L.M. 1995. Tectonic stylolites in the 'undeformed' Cumberland Plateau of southern Tennessee. Journal of Structural Geology, 17(6), 911-915.

Raynaud, S., \& Carrio-Schaffhauser, E. 1992. Rock matrix structures in a zone influenced by a stylolite. Journal of Structural Geology, 14(8-9), 973-980.

Renard, F., Schmittbuhl, J., Gratier, J.P., Meakin, P. and Merino, E. 2004. Three-dimensional roughness of stylolites in limestones. Journal of Geophysical Research: Solid Earth, 109(B3), B03209, doi:10.1029/2003JB002555.

Rolland, A., Toussaint, R., Baud, P., Schmittbuhl, J., Conil, N., Koehn, D., Renard, F. and Gratier, J.P. 2012. Modeling the growth of stylolites in sedimentary rocks. Journal of Geophysical Research: Solid Earth, 117(B6), B06403, doi:10.1029/2011JB009065.

Rolland, A., Toussaint, R., Baud, P., Conil, N., \& Landrein, P. 2014. Morphological analysis of stylolites for paleostress estimation in limestones. International Journal of Rock Mechanics and Mining Sciences, 67, 212-225.

Rustichelli, A., Tondi, E., Agosta, F., Cilona, A. and Giorgioni, M. 2012. Development and distribution of bed-parallel compaction bands and pressure solution seams in carbonates (Bolognano Formation, Majella Mountain, Italy). Journal of Structural Geology, 37, 181-199.

Rustichelli, A., Tondi, E., Korneva, I., Baud, P., Vinciguerra, S., Agosta, F., Reuschlé, T. and Janiseck, J.M. 2015. Bedding-parallel stylolites in shallow-water limestone successions of the Apulian Carbonate Platform (central-southern Italy). Italian Journal of Geosciences, 134(3), 513-534.

Scheidegger, A. E. 1974. The Physics of Flow through Porous Media (No. 532.5 S2 1974).

Schmittbuhl, J., Renard, F., Gratier, J.P. and Toussaint, R. 2004. Roughness of stylolites: implications of 3D high resolution topography measurements. Physical Review Letters, 93(23), p.238501.

Smith, S. A., Billi, A., Di Toro, G., \& Spiess, R. 2011. Principal slip zones in limestone: microstructural characterization and implications for the seismic cycle (Tre Monti Fault, Central Apennines, Italy). Pure and Applied Geophysics, 168(12), 2365-2393.

Tanikawa, W., \& Shimamoto, T. 2006. Klinkenberg effect for gas permeability and its comparison to water permeability for porous sedimentary rocks. Hydrology and Earth System Sciences Discussions, 3(4), 1315-1338.

Tanikawa, W., \& Shimamoto, T. 2009. Comparison of Klinkenberg-corrected gas permeability and water permeability in sedimentary rocks. International Journal of Rock Mechanics and Mining Sciences, 46(2), 229-238.

Toby, B. H. 2001. EXPGUI, a graphical user interface for GSAS. Journal of Applied Crystallography, 34(2), 210-213.

Tondi, E., Antonellini, M., Aydin, A., Marchegiani, L. and Cello, G. 2006. The role of deformation bands, stylolites and sheared stylolites in fault development in carbonate grainstones of Majella Mountain, Italy. Journal of Structural Geology, 28(3), 376-391.

Toussaint, R., Aharonov, E., Koehn, D., Gratier, J. P., Ebner, M., Baud, P., ... \& Renard, F. (2018). Stylolites: A review. Journal of Structural Geology, 114, 163-195.

Vajdova, V., Baud, P., \& Wong, T. F. 2004. Permeability evolution during localized deformation in Bentheim sandstone. Journal of Geophysical Research: Solid Earth, 109(B10), B10406, doi:10.1029/2003JB002942. 
801 Van Geet, M., Swennen, R., \& Wevers, M. 2000. Quantitative analysis of reservoir rocks by 802 microfocus X-ray computerised tomography. Sedimentary Geology, 132(1-2), 25-36.

803 Walderhaug, 0. 1996. Kinetic modeling of quartz cementation and porosity loss in deeply buried 804 sandstone reservoirs. AAPG bulletin, 80(5), 731-745.

805 Walderhaug, 0., \& Bjørkum, P. A. (2003). The effect of stylolite spacing on quartz cementation in the 806 Lower Jurassic Stø Formation, southern Barents Sea. Journal of Sedimentary Research, 73(2), 807 146-156.

810

Wanless, H.R. 1979. Limestone response to stress: pressure solution and dolomitization. Journal of Sedimentary Research, 49(2), 437-462.

Zinszner, B., \& Pellerin, F. M. 2007. A Geoscientist's Guide to Petrophysics. Editions Technip. ISBN: 9782710808992. 